\title{
Luminescence studies of new [C,N,N'] cyclometallated platinum(II) and platinum(IV) compounds
}

Ariadna Lázaro, ${ }^{a}$ Oriol Serra, ${ }^{a}$ Laura Rodríguez, ${ }^{*},{ }^{\mathrm{a}, \mathrm{b}}$ Margarita Crespo, ${ }^{* a, \mathrm{c}}$ and Mercè Font-Bardia $^{\mathrm{d}}$

a Departament de Química Inorgànica i Orgànica, Secció de Química Inorgànica, Facultat de Química, Universitat de Barcelona, Martí i Franquès, 1-11, 08028-Barcelona (Spain)

${ }^{b}$ Institut de Nanociència i Nanotecnologia (IN2UB). Universitat de Barcelona, 08028Barcelona (Spain)

${ }^{c}$ Institut de Biomedicina de la Universitat de Barcelona (IBUB). 08028-Barcelona (Spain)

${ }^{d}$ Unitat de Difracció de $R X$, Centres Científics i Tecnològics de la Universitat de Barcelona (CCiTUB), Universitat de Barcelona, Solé i Sabaris 1-3, 08028-Barcelona (Spain)

*Corresponding authors: Laura Rodríguez (E-mail:laura.rodriguez@qi.ub.es); Margarita Crespo (E-mail:margarita.crespo@qi.ub.es) 


\begin{abstract}
The synthesis of six novel cyclometallated platinum(IV) compounds (3a-3c and $\mathbf{4 a - 4 c})$ derived from ligand $\left(4-\mathrm{FC}_{6} \mathrm{H}_{4}\right) \mathrm{CH}=\mathrm{N}\left(\mathrm{CH}_{2}\right)_{3} \mathrm{~N}\left(\mathrm{CH}_{3}\right)_{2}(\mathbf{L})$ was achieved by intermolecular oxidative addition of halogens to cyclometallated platinum(II) compounds $\left[\mathrm{Pt}\left(\mathrm{CH}_{3}\right)\left\{\left(\mathrm{CH}_{3}\right)_{2} \mathrm{~N}\left(\mathrm{CH}_{2}\right)_{3} \mathrm{~N}=\mathrm{CH}\left(4-\mathrm{FC}_{6} \mathrm{H}_{3}\right)\right\}\right] \quad$ (1) and $\quad\left[\mathrm{PtX}\left\{\left(\mathrm{CH}_{3}\right)_{2} \mathrm{~N}\left(\mathrm{CH}_{2}\right)_{3} \mathrm{~N}=\mathrm{CH}(4-\right.\right.$ $\left.\left.\left.\mathrm{FC}_{6} \mathrm{H}_{3}\right)\right\}\right]$ (2a, $\mathrm{X}=\mathrm{Cl} ; \mathbf{2} \mathbf{b}, \mathrm{X}=\mathrm{Br} ; \mathbf{2} \mathbf{c}, \mathrm{X}=\mathrm{I}$ ). While compound $\mathbf{2 b}$ could be obtained from 2a through $\mathrm{Cl}$ for $\mathrm{Br}$ substitution reaction, 2c was best obtained through cyclometallation of ligand $\mathbf{L}$ with $\left[\mathrm{PtI}_{2}(\mathrm{dmso})_{2}\right]$. The X-ray molecular structures of [C,N,N'] platinum(II) (2b) and platinum(IV) (3b and 4b) cyclometallated compounds and of the [N,N'] platinum (II) compound Ib, all of them containing bromido ligands, are reported. The absorption and emission spectra were also studied in dichloromethane solution at room temperature. All compounds, except $\mathbf{3 c}$ and $\mathbf{4 c}$ arising from oxidative addition of iodine, display a broad emission band in the $340-360 \mathrm{~nm}$ range, attributed to platinum disturbed intraligand (IL) transitions, when excited at the highest energy band, and higher emission intensities were observed, in general, for cyclometallated platinum(IV) compounds.
\end{abstract}

\title{
INTRODUCTION
}

A large number of materials that can be applied as phosphorescent emitters in organic light-emitting diodes (OLEDs) are coordination compounds of the heavy late transition metals and many of them are cyclometallated complexes. A key to minimize nonradiative decay is to use strong field ligands so that metal centered d-d states are not energetically accessible at room temperature. Aromatic cyclometallating ligands are attractive since in addition to strong ligand-field, these ligands produce generally rigid five-membered rings. Since rigidity generally favors luminescence over non-radiative decay pathways, tridentate ligands offer an advantage over bidentate ligands. In 
particular, many cyclometallated platinum complexes are luminescent in solution and those containing tridentate $[\mathrm{C}, \mathrm{N}, \mathrm{N}]$ or $[\mathrm{N}, \mathrm{C}, \mathrm{N}]$ monoanionic ligands attract a great deal of interest as phosphorescent materials. The ancillary ligands completing the coordination of platinum and the substituents on the aryl ring are also crucial in the emission properties. ${ }^{1-4}$ In addition, many cyclometallated platinum compounds display anticancer activity and are attractive to be used as bioimaging agents. ${ }^{5-7}$

In spite of the great number of planar cyclometallated platinum(II) compounds for which the luminescence properties have been reported, cyclometallated platinum(IV) compounds have received less attention. ${ }^{8-10}$

In a previous study, we have analysed the synthetic method and the luminescence properties of platinum(II) cyclometallated compounds containing a tridentate $\left[\mathrm{C}, \mathrm{N}^{\prime} \mathrm{N}^{\prime}\right]$ imine ligand with fluoro substituents. ${ }^{11}$ In this work, we report the synthesis and luminescence properties of cyclometallated platinum(II) and platinum(IV) compounds containing a tridentate $\left[\mathrm{C}, \mathrm{N}, \mathrm{N}^{\prime}\right]$ imine ligand with a para-fluoro substituent and methyl or halido (chlorido, bromido or iodido) ligands. The effect of the nature of the ancillary ligand and of the oxidation state of the platinum atom on the emission properties of these compounds will be analysed.

\section{RESULTS AND DISCUSSION}

\section{Synthesis and characterization of the compounds}

Ligand (4- $\left.\mathrm{FC}_{6} \mathrm{H}_{4}\right) \mathrm{CH}=\mathrm{N}\left(\mathrm{CH}_{2}\right)_{3} \mathrm{~N}\left(\mathrm{CH}_{3}\right)_{2}(\mathbf{L})$ was selected for this study since, according to previous results, ${ }^{11}$ this ligand allows formation of luminescent tridentate $\left[\mathrm{C}, \mathrm{N}, \mathrm{N}^{\prime}\right]$ platinum(II) compounds and the presence of a fluoro substituent in para leads to higher quantum yields. In this work, cyclometallated platinum(II) compounds derived from 
ligand $\mathbf{L}$ and containing $\mathrm{CH}_{3}, \mathrm{Cl}, \mathrm{Br}$ or I as ancillary ligand will be prepared and halogen oxidative addition to these compounds will yield the corresponding cyclometallated platinum(IV) compounds.

The synthesis of compounds $\mathbf{1}$ and $\mathbf{2 a}$, depicted in scheme 1, has been previously reported from ligand $\mathbf{L}$ and using as metallating agents dimer $\left[\mathrm{Pt}_{2}\left(\mathrm{CH}_{3}\right)_{4}\left(\mu-\mathrm{S}\left(\mathrm{CH}_{3}\right)_{2}\right)_{2}\right](\mathbf{D})$ or compound cis-[ $\left.\mathrm{PtCl}_{2}(\mathrm{dmso})_{2}\right]$ (A). The synthesis of new cyclometallated platinum(II) compounds $\left[\operatorname{PtBr}\left\{\left(\mathrm{CH}_{3}\right)_{2} \mathrm{~N}\left(\mathrm{CH}_{2}\right)_{3} \mathrm{~N}=\mathrm{CH}\left(4-\mathrm{FC}_{6} \mathrm{H}_{3}\right)\right\}\right]$ and $\left[\operatorname{PtI}\left\{\left(\mathrm{CH}_{3}\right)_{2} \mathrm{~N}\left(\mathrm{CH}_{2}\right)_{3} \mathrm{~N}=\mathrm{CH}\left(4-\mathrm{FC}_{6} \mathrm{H}_{3}\right)\right\}\right]$ (2c) was attempted following the same method than for compound $2 \mathbf{a}$ using analogous cis- $\left[\mathrm{PtX} \mathrm{X}_{2}(\mathrm{dmso})_{2}\right]$ precursors $(\mathbf{B}, \mathrm{X}=\mathrm{Br}$ or $\mathbf{C}, \mathrm{X}$ $=\mathrm{I})$. This type of cyclometallation reactions can be carried out as one-pot procedure from the metallating agent and the ligand which are refluxed for several hours in a donor solvent in the presence of sodium acetate. Alternatively, the corresponding [N,N']-chelate complex can be isolated and such complexes further react to yield cycloplatinated derivatives via $\mathrm{C}-\mathrm{H}$ activation (see scheme 1). ${ }^{11-14}$ These reactions generally require prolonged reaction times and give moderate yields. In the present study, compound $\left[\operatorname{PtI}\left\{\left(\mathrm{CH}_{3}\right)_{2} \mathrm{~N}\left(\mathrm{CH}_{2}\right)_{3} \mathrm{~N}=\mathrm{CH}\left(4-\mathrm{FC}_{6} \mathrm{H}_{3}\right)\right\}\right]$ (2c) was best obtained using the one-pot procedure. In contrast, the bromo derivative $\left[\operatorname{PtBr}\left\{\left(\mathrm{CH}_{3}\right)_{2} \mathrm{~N}\left(\mathrm{CH}_{2}\right)_{3} \mathrm{~N}=\mathrm{CH}\left(4-\mathrm{FC}_{6} \mathrm{H}_{3}\right)\right\}\right]$ (2b) could not be obtained in a pure form neither using the one-pot procedure nor with prior isolation of the $\left[\mathrm{N}, \mathrm{N}^{\prime}\right]$-chelate complex $\mathbf{I b}$, since the obtained compound was impurified with small amounts of Ib. In view of these results, the synthesis of compound 2b was carried out from compound $\left[\mathrm{PtCl}\left\{\left(\mathrm{CH}_{3}\right)_{2} \mathrm{~N}\left(\mathrm{CH}_{2}\right)_{3} \mathrm{~N}=\mathrm{CH}\left(4-\mathrm{FC}_{6} \mathrm{H}_{3}\right)\right\}\right]$ (2a) which was treated with an excess of $\mathrm{KBr}$ in refluxing methanol so that chlorido for bromido substitution took place. 


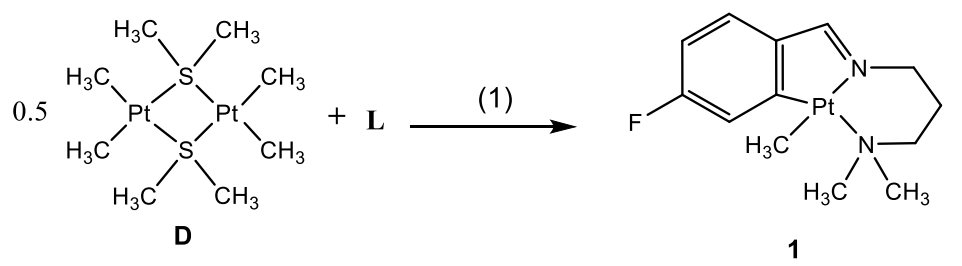<smiles></smiles>

$2 a$

(4)<smiles></smiles><smiles>CO[Pb](I)(I)O[Na]</smiles>

(2)

Scheme 1. Synthesis of cyclometallated platinum(II) compounds. (1): toluene, reflux 1h; (2): + sodium acetate, methanol, reflux, 72 h; (3) methanol, reflux, 4h; (4): + KBr, methanol, reflux, 48 $\mathrm{h}$. The numbering scheme used for NMR is shown for the new compounds. 
Compounds Ib, Ic, $2 \mathbf{b}$ and $\mathbf{2 c}$ were characterised by ${ }^{1} \mathrm{H}$ and ${ }^{19} \mathrm{~F}$ NMR, mass spectra and elemental analyses which were consistent with the structures depicted in Scheme 1. For both compounds Ib and Ic containing a chelate [N,N'] ligands, the imine proton is coupled to platinum and the value of the coupling $\left({ }^{3} J(\mathrm{Pt}-\mathrm{H})=115.6 \mathrm{~Hz}\right)$ indicates that the imine adopts the $E$ configuration in which the imine proton is trans to the platinum atom. ${ }^{11}$ This configuration is the most favoured for achieving the intramolecular $\mathrm{C}-\mathrm{H}$ bond activation since it brings the aryl ligand close to the halido ligand. For compounds 2b and 2c, the ${ }^{1} \mathrm{H}$ NMR spectra confirm the formation of the expected fused $[6,5,6]-$ tricyclic systems. As reported for analogous systems, ${ }^{12-13,15-16 ~} 3 \mathrm{~J}(\mathrm{Pt}-\mathrm{H})$ values (143.7 and 135.8 Hz) for the imine proton are higher than those obtained for compounds I. The proton adjacent to the metallated carbon $\left(\mathrm{H}^{\mathrm{a}}\right)$ is also coupled to platinum and the ${ }^{3} J(\mathrm{Pt}-\mathrm{H})$ values are in the range expected $(c a .40 \mathrm{~Hz})$. It is interesting to point out that the chemical shift of $\mathrm{H}^{\mathrm{a}}$ depends on the nature of the halido group cis to the aryl and, as shown in figure $\mathrm{S} 1$, moves downfield following the sequence $\mathrm{Cl}(7.72 \mathrm{ppm})<\mathrm{Br}(8.00 \mathrm{ppm})<\mathrm{I}(8.45$ ppm). Although a decrease in the chemical shift of a nucleus with increasing atomic number of the vicinal halogen is frequently observed, inverse halogen dependence is also occasionally seen, and it has been suggested that the chemical shifts could be affected by spin-orbit coupling. ${ }^{17}$

Compounds Ib and $\mathbf{2 b}$ were also characterised by single crystal X ray diffraction and the structures are shown in figures 1 and 2. Two (Ib) and three (2b) independent molecules with bond parameters equal within experimental error $[3 \sigma]$ are present in the asymmetric unit (see figures S2 and S3). In both cases, the platinum adopts a square-planar coordination. For $\mathbf{I b}$, the ligand adopts a bidentate $\left[\mathrm{N}, \mathrm{N}^{\prime}\right]$ coordination and the coordination is completed with two mutually cis bromido ligands. As observed in the ${ }^{1} \mathrm{H}$ NMR spectra, the ligand adopts an $E$ configuration around the imine moiety, so that the 
phenyl ring is close to the platinum. As for $\mathbf{2} \mathbf{b}$, the square-planar coordination of the platinum is completed with a tridentate $\left[\mathrm{C}, \mathrm{N}, \mathrm{N}^{\prime}\right]$ ligand and a bromido ligand trans to the imine. As a result, a fused [6,5,6]-tricyclic system containing an ortho-metalated phenyl group, a five-membered platinacycle and a six-membered chelate ring with two nitrogen atoms coordinated to platinum is formed.

Bond lengths and angles are well within the range of values obtained for analogous compounds. ${ }^{11-13}$ No significant differences are observed for Pt-Br distances which lie in the range 2.4238-2.4302 $\mathrm{A}$. In both compounds, the Pt-amine distances are greater than Pt-imine distances in agreement with the weaker ligating ability of amines for platinum, and Pt-amine distance is higher $(2.197 \AA)$ for $\mathbf{2 b}$ than for $\mathbf{I b}(2.093 \AA)$ in agreement with the greater trans influence of the aryl versus the bromido ligand. Most angles at platinum are close to the ideal value of $90^{\circ}$, and the smallest angle corresponds to the chelate angle $\mathrm{N}(1)-\mathrm{Pt}-\mathrm{N}(2)$ for $\mathbf{I b}\left(89.27(10)^{\mathbf{o}}\right)$ or to the metallacycle $\mathrm{C}(1)-\mathrm{Pt}-\mathrm{N}(1)$ for $\mathbf{2 b}\left(80.8(3)^{\mathbf{o}}\right)$. For the latter, as previously observed for analogous cyclometallated compounds ${ }^{11,12}$ and in agreement with the flexibility of the ligands derived from propylenediamine, the chelate angle $\mathrm{N}(1)-\mathrm{Pt}-\mathrm{N}(2)$ increases up to $95.8(3)^{\circ}$.

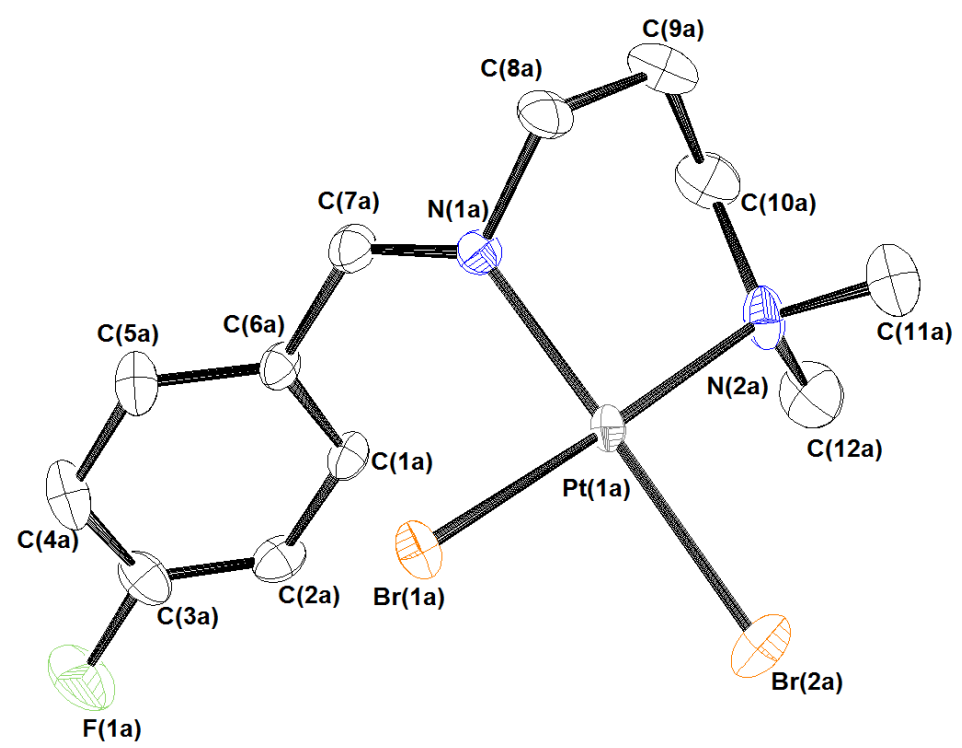


Figure 1. Molecular structure of compound Ib (molecule a). Selected bond lengths $(\AA)$ and angles (deg.) with estimated standard deviations: $\mathrm{Pt}(1 \mathrm{a})-\mathrm{N}(1 \mathrm{a}): 2.016(2) ; \mathrm{Pt}(1 \mathrm{a})-\mathrm{N}(2 \mathrm{a})$ : 2.093(2); $\mathrm{Pt}(1 \mathrm{a})-$ $\operatorname{Br}(1 \mathrm{a}): 2.4248(3) ; \operatorname{Pt}(1 \mathrm{a})-\mathrm{Br}(2 \mathrm{a}): 2.4238(3) ; \mathrm{N}(1 \mathrm{a})-\operatorname{Pt}(1 \mathrm{a})-\mathrm{N}(2 \mathrm{a}): 89.27(10) ; \mathrm{N}(1 \mathrm{a})-\operatorname{Pt}(1 \mathrm{a})-\mathrm{Br}(1 \mathrm{a})$ : 88.96(7); N(2a)-Pt(1a)-Br(2a): 92.36(7); $\operatorname{Br}(1 \mathrm{a})-\operatorname{Pt}(1 \mathrm{a})-\operatorname{Br}(2 \mathrm{a}): 89.361(11)$.

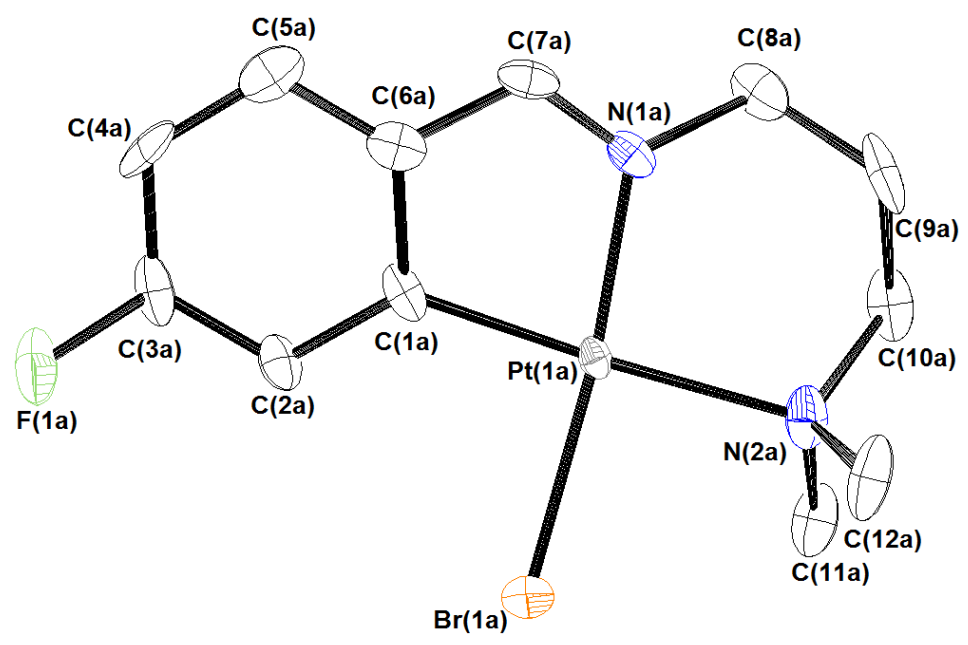

Figure 2. Molecular structure of compound $\mathbf{2 b}$ (molecule a). Selected bond lengths $(\AA)$ and angles (deg.) with estimated standard deviations: $\mathrm{Pt}(1 \mathrm{a})-\mathrm{C}(1 \mathrm{a})$ : 1.993(9); $\mathrm{Pt}(1 \mathrm{a})-\mathrm{N}(1 \mathrm{a})$ : 2.019(7); $\mathrm{Pt}(1 \mathrm{a})-$ N(2a): 2.197(8); $\operatorname{Pt}(1 \mathrm{a})-\mathrm{Br}(1 \mathrm{a}): 2.4302(10) ; \mathrm{C}(1 \mathrm{a})-\operatorname{Pt}(1 \mathrm{a})-\mathrm{N}(1 \mathrm{a}): 80.8(3) ; \mathrm{N}(1 \mathrm{a})-\operatorname{Pt}(1 \mathrm{a})-\mathrm{N}(2 \mathrm{a})$ : 95.8(3); C(1a)-Pt(1a)-Br(1a): 92.7(3); N(2a)-Pt(1a)-Br(1a): 90.5(2).

Cyclometallated platinum(IV) compounds $\left[\mathrm{Pt}\left(\mathrm{CH}_{3}\right) \mathrm{X}_{2}\left\{\left(\mathrm{CH}_{3}\right)_{2} \mathrm{~N}\left(\mathrm{CH}_{2}\right)_{3} \mathrm{~N}=\mathrm{CH}(4-\right.\right.$ $\left.\left.\left.\mathrm{FC}_{6} \mathrm{H}_{3}\right)\right\}\right](\mathbf{3 a}, \mathbf{3 b}, \mathbf{3 c})$ were synthesized by oxidative addition of $\mathrm{Cl}_{2}(\mathbf{3 a}), \mathrm{Br}_{2}(\mathbf{3 b})$ or $\mathrm{I}_{2}$ (3c) to cyclometallated platinum(II) compound $\mathbf{1}$ in acetone at room temperature (Scheme 2). According to previously reported procedures, ${ }^{18-19}$ iodobenzene dichloride was used in the synthesis of 3a to avoid the handling of $\mathrm{Cl}_{2}$ gas. The proposed mechanisms for halogen oxidative addition reactions point to the formation of octahedral platinum(IV) compounds in which the new ligands are mutually trans as depicted in scheme $2 .{ }^{18-21}$ Nevertheless, further isomerisation reactions might bring these ligands to mutually cis positions. In this study, ${ }^{1} \mathrm{H}$ NMR spectra carried out for compounds 3 indicated the presence of only one isomer in each case. The obtained data (discussed below) are 
consistent with the fact that the two halido ligands are mutually trans for $\mathbf{3 b}$ and $\mathbf{3 c}$ and mutually cis for 3a. The isomerisation of compound 3a could arise from exchange of the positions of the chlorido and the methyl ligands, although taking into account the low lability of $\mathrm{Pt}-\mathrm{C}$ bonds, a mer to $f a c-\left[\mathrm{C}, \mathrm{N}, \mathrm{N}^{\prime}\right]$ isomerisation of the tridentate ligand, as described for analogous cyclometallated platinum(IV) compounds, with exchange of the dimethylamino moiety and the chlorido ligand is also possible. ${ }^{14,22,23}$ These processes are depicted in scheme 3, and we might assume that they do not take place for $\mathbf{3 b}$ and $\mathbf{3 c}$ since a higher stability is obtained if the more bulky bromido or iodido ligands remain in axial positions in agreement with previous results for analogous compounds. ${ }^{24}$<smiles>CN1CCCN2C=C3C=CC(F)=CC3P12(C)C</smiles>

1<smiles>[X][P+]1(C)c2cc(F)ccc2CN1CCCN(C)C</smiles>

2a $\mathrm{X}=\mathrm{Cl}$

$2 \mathrm{~b} X=\mathrm{Br}$

$2 \mathrm{c} X=1$
(1)<smiles>[X][P+]([X])(C)N(C)CCCN(C)C</smiles>

3a $\mathrm{X}=\mathrm{C}$

$3 \mathbf{b} X=\mathrm{Br}$

$3 c X=1$

(2)

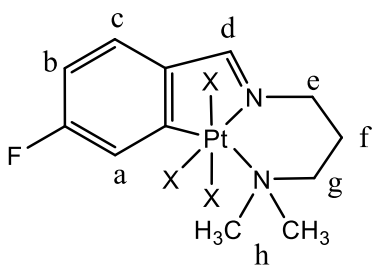

$4 \mathrm{a} X=\mathrm{Cl}$

4b $X=B r$

$4 c X=1$

Scheme 2. Synthesis of cyclometallated platinum(IV) compounds. (1): $+\mathrm{PhICl}_{2}(\mathbf{3 a}),+\mathrm{Br}_{2}(\mathbf{3 b})$, $+\mathrm{I}_{2}(\mathbf{3 c})$, acetone, r.t., $1 \mathrm{~h} ;(2):+\mathrm{PhICl}_{2}(\mathbf{4 a}),+\mathrm{Br}_{2}(\mathbf{4 b}),+\mathrm{I}_{2}(\mathbf{4 c})$, acetone, r.t., 1 h. The numbering scheme used for NMR is shown for the new compounds.

Cyclometallated platinum(IV) compounds $\left[\mathrm{PtX}_{3}\left\{\left(\mathrm{CH}_{3}\right)_{2} \mathrm{~N}\left(\mathrm{CH}_{2}\right)_{3} \mathrm{~N}=\mathrm{CH}\left(4-\mathrm{FC}_{6} \mathrm{H}_{3}\right)\right\}\right](\mathbf{4 a}$, $\mathrm{X}=\mathrm{Cl} ; \mathbf{4 b}, \mathrm{X}=\mathrm{Br} ; \mathbf{4 c}, \mathrm{X}=\mathrm{I})$ containing three halido ligands of the same nature were 
synthesised following the same procedures used to prepare compounds $\mathbf{3}$ and were obtained as single isomers (see scheme 2).

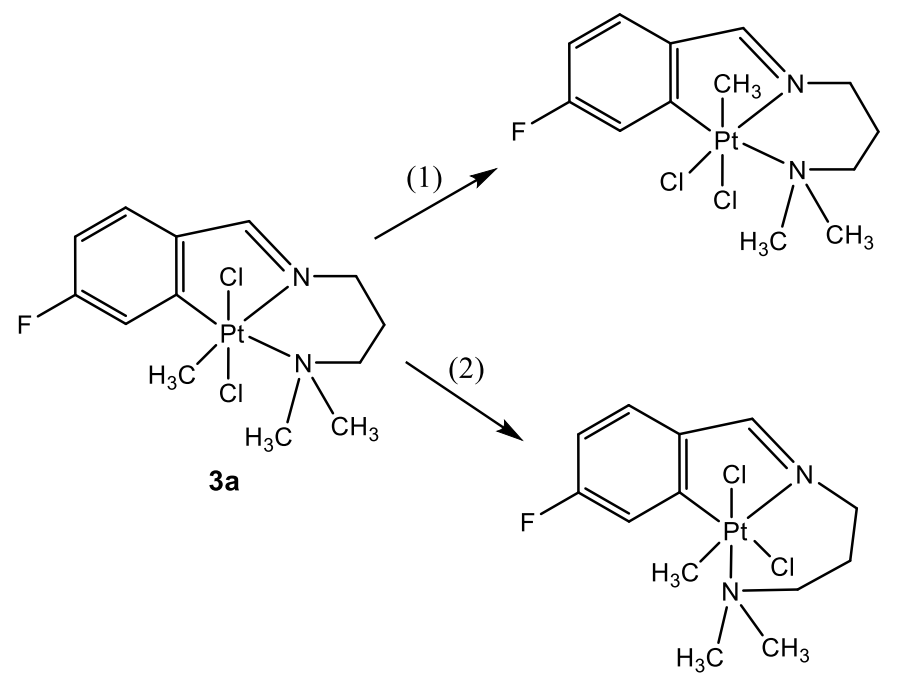

Scheme 3. Possible isomerization paths for compound 3a. (1): $\mathrm{CH}_{3} / \mathrm{Cl}$ exchange; (2): $\mathrm{N}\left(\mathrm{CH}_{3}\right)_{2} / \mathrm{Cl}$ exchange.

Cyclometallated platinum(IV) compounds $\mathbf{3 a - 3 c}$ and $\mathbf{4 a - 4} \mathbf{c}$ were characterized by ${ }^{1} \mathrm{H}$ and ${ }^{19}$ F-NMR spectroscopy, MS-ESI ${ }^{+}$and elemental analysis. For 3a, the platinum(IV) centre becomes chiral due to the trans $-\mathrm{Cl}_{2} /$ cis $-\mathrm{Cl}_{2}$ isomerization process indicated above and, therefore, the $\mathrm{N}\left(\mathrm{CH}_{3}\right)_{2}$ and the $\left(\mathrm{CH}_{2}\right)_{3}$ protons are diastereotopic. All other compounds display simpler ${ }^{1} \mathrm{H}$ NMR spectra in which the dimethylamino and the methylene protons are equivalent. Selected ${ }^{1} \mathrm{H}$ NMR data for these compounds are collected in Table 1. In all cases, the imine proton is coupled to ${ }^{195} \mathrm{Pt}$ and the ${ }^{3} J(\mathrm{Pt}-\mathrm{H})$ values are in the range 44.647.2 Hz for compounds 3 and 91.2-95.7 for compounds 4. These values are in agreement with the increased oxidation state of platinum and with the nature of the ligand in trans to the imine $\left(\mathrm{CH}_{3}\right.$ for compounds 3 and halido for compounds 4$)$. In most cases, ${ }^{3} J(\mathrm{Pt}-\mathrm{H})$ values were also observed for dimethylamino protons in the range 10.2-16.6 Hz and for the proton adjacent to the metalation site $\left(\mathrm{H}^{\mathrm{a}}\right)$ in the range $33.3-38.2 \mathrm{~Hz}$, thus confirming 
the tridentate $\left[\mathrm{C}, \mathrm{N}, \mathrm{N}^{\prime}\right]$ coordination of the imine ligand. In addition, for compounds $\mathbf{3}$, the methyl group is also coupled to platinum and the ${ }^{2} J(\mathrm{Pt}-\mathrm{H})$ values $(59.6-68.3 \mathrm{~Hz})$ are reduced compared to those of the parent platinum(II) compound $\mathbf{1}$. The methyl resonance in compounds $\mathbf{3}$ is shifted downfield $(\mathbf{3 a}, \delta=1.80 ; \mathbf{3 b}, \delta=1.99 ; \mathbf{3} \mathbf{c}, \delta=2.26)$ as the size of the halido ligand increases. As shown in figure S4, the size of the halido ligand affects the chemical shift of the imine proton which decreases for both series of compounds 3 and $\mathbf{4}$ as the halido size increases. In addition, for compounds $\mathbf{4}$, the chemical shift of the proton adjacent to the metallation site $\left(\mathrm{H}^{\mathrm{a}}\right)$ increases as the bulk of the halido ligand increases.

Table 1.- Selected ${ }^{1} \mathrm{H}$ NMR data for the studied compounds. ${ }^{a}$

\begin{tabular}{cccc}
\hline \hline & $\delta\left(\mathrm{H}^{\mathrm{d}}\right)\left[{ }^{3} J(\mathrm{Pt}-\mathrm{H})\right]$ & $\delta\left(\mathrm{H}^{\mathrm{a}}\right)\left[{ }^{3} J(\mathrm{Pt}-\mathrm{H})\right]$ & $\delta\left(\mathrm{CH}_{3}\right)\left[{ }^{2} J(\mathrm{Pt}-\mathrm{H})\right]$ \\
\hline \hline $\mathbf{1}^{\mathrm{b}}$ & $8.66[62.8]$ & $7.21[35.6]$ & $0.81[81.7]$ \\
\hline $\mathbf{2 a}^{\mathrm{b}}$ & $8.32[141.6]$ & $7.72[40.0]$ & - \\
\hline $\mathbf{2 b}$ & $8.33[143.7]$ & $8.00[46.6]$ & - \\
\hline $\mathbf{2 c}$ & $8.38[135.8]$ & $8.45[39.8]$ & - \\
\hline $\mathbf{3 a}$ & $8.49[45.5]$ & $7.01\left[^{\mathrm{c}}\right]$ & $1.80[59.6]$ \\
\hline $\mathbf{3 b}$ & $8.37[44.6]$ & $7.02[33.3]$ & $1.99[67.6]$ \\
\hline $\mathbf{3 c}$ & $8.21[47.2]$ & $7.02[38.2]$ & $2.26[68.3]$ \\
\hline $\mathbf{4 a}$ & $8.19[95.7]$ & $7.78\left[{ }^{\mathrm{c}}\right]$ & - \\
\hline $\mathbf{4 b}$ & $8.09[93.9]$ & $7.97\left[{ }^{\mathrm{c}}\right]$ & - \\
\hline $\mathbf{4 c}$ & $7.96[91.2]$ & $8.25[33.6]$ & - \\
\hline
\end{tabular}

\footnotetext{
${ }^{\text {a }}$ In $\mathrm{CDCl}_{3}, \delta$ in ppm, $J$ in $\mathrm{Hz}$, labels as indicated in Schemes 1 and $2 .{ }^{\mathrm{b}}$ Values as previously
} reported. ${ }^{11}{ }^{\mathrm{c}}$ Not observed. 
Compounds $\mathbf{3 b}$ and $\mathbf{4 b}$ were also characterized by single crystal $\mathrm{X}$ ray diffraction and the structures are shown in figures 3 and 4.

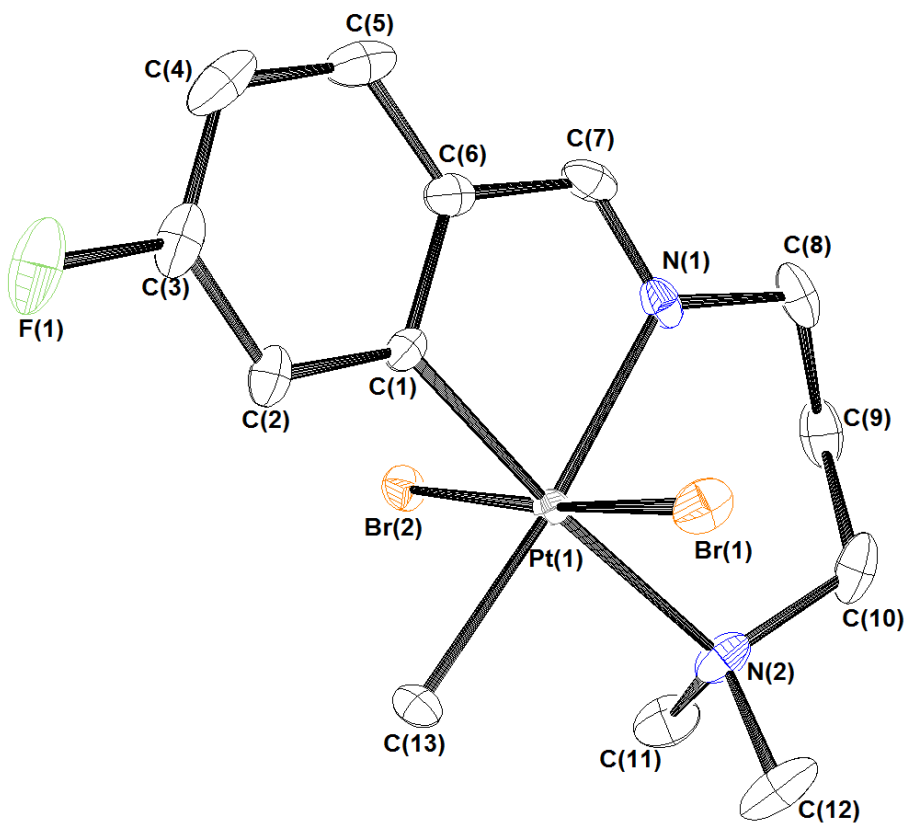

Figure 3. Molecular structure of compound 3b. Selected bond lengths ( $\AA$ ) and angles (deg.) with estimated standard deviations: $\mathrm{Pt}(1)-\mathrm{C}(1), 2.007(3) ; \mathrm{Pt}(1)-\mathrm{C}(13), 2.135(3) ; \mathrm{Pt}(1)-\mathrm{N}(1), 2.141(2)$; $\mathrm{Pt}(1)-\mathrm{N}(2), 2.258(3) ; \mathrm{Pt}(1)-\mathrm{Br}(1), 2.4485(3) ; \mathrm{Pt}(1)-\mathrm{Br}(2), 2.4675(3) ; \mathrm{C}(1)-\mathrm{Pt}(1)-\mathrm{C}(13), 94.51(11)$; C(1)-Pt(1)-N(1), 79.97(11); C(13)-Pt(1)-N(2)，90.27(10); N(1)-Pt(1)-N(2)，95.28(10); C(1)$\mathrm{Pt}(1)-\mathrm{Br}(1), 86.43(8) ; \mathrm{C}(13)-\mathrm{Pt}(1)-\mathrm{Br}(1), 91.27(8) ; \mathrm{N}(1)-\mathrm{Pt}(1)-\mathrm{Br}(1), 89.37(7) ; \mathrm{N}(2)-\mathrm{Pt}(1)-\mathrm{Br}(1)$, 90.95(7); C(1)-Pt(1)-Br(2), 87.53(8); C(13)-Pt(1)-Br(2), 89.49(8); N(1)-Pt(1)-Br(2), 89.29(7); $\mathrm{N}(2)-\operatorname{Pt}(1)-\operatorname{Br}(2), 95.05(7)$.

As expected from NMR studies, for both compounds, the platinum atom displays an octahedral coordination with a meridional tridentate [C,N,N'] ligand. An equatorial methyl and two bromido ligands $(\mathbf{3 b})$ or three bromido ligands $(\mathbf{4 b})$ complete the coordination around the platinum. Bond lengths and angles are well within the range of values obtained for analogous compounds. ${ }^{14}$ The main distortions from the ideal octahedral coordination correspond to the small bite angle of the metallacycles $(\mathbf{3 b}$, $79.97(11)^{\mathbf{o}}$ and $\left.\mathbf{4 b}, 80.3(3)^{\mathbf{o}}\right)$ and the large value of the $\left[\mathrm{N} \mathrm{N}^{\prime}\right]$ chelate $\left(\mathbf{3 b}, 95.28(10)^{\mathbf{o}}\right.$ and 
4b, 96.2(3) ${ }^{\circ}$. The axial ligand form a Br-Pt-Br angle of 173.947(11) (3b) or 173.99(3) (4b). As observed for $\mathbf{2 b}$, the Pt-amine distances (3b, 2.258 and $\mathbf{4 b}, 2.276 \AA$ ) are greater than Pt-imine distances (3b, 2.141 and $\mathbf{4 b}, 2.032 \AA$ ) and the Pt-imine distance is longer for $\mathbf{3 b}$ (trans to a methyl ligand) than for $\mathbf{4 b}$ (trans to a bromido ligand) in agreement with the higher trans-influence of C-donor ligands. This is consistent with the lower coupling constant of the imine proton observed by ${ }^{1} \mathrm{H}$ NMR spectroscopy for compound 3b. A comparison of the bond distances of the cyclometallated platinum(IV) compounds with those of the platinum(II) precursor $2 \mathbf{b}$ reveals that the Pt- $\mathrm{N}_{\text {imine, }}, \mathrm{Pt}-\mathrm{N}_{\text {amine }}$ and Pt-C bond lengths are moderately longer for the platinum(IV) compounds. ${ }^{14}$

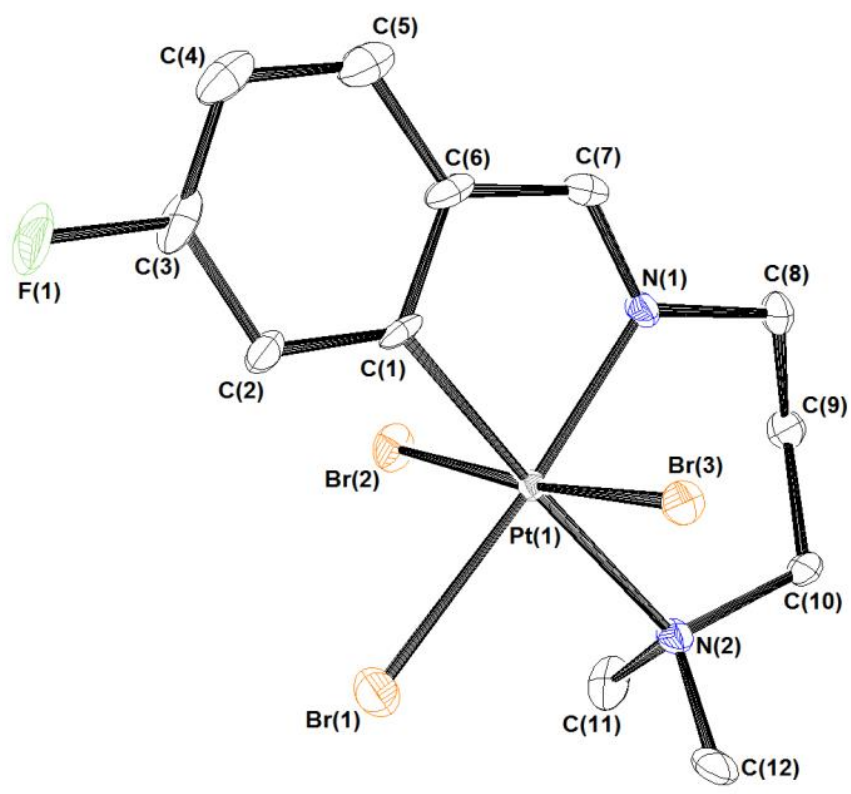

Figure 4. Molecular structure of compound $\mathbf{4 b}$. Selected bond lengths $(\AA)$ and angles (deg.) with estimated standard deviations: $\mathrm{Pt}(1)-\mathrm{C}(1), 2.027(9) ; \mathrm{Pt}(1)-\mathrm{N}(1), 2.032(8) ; \mathrm{Pt}(1)-\mathrm{N}(2), 2.276(8)$; $\mathrm{Pt}(1)-\mathrm{Br}(1), 2.4496(10) ; \operatorname{Pt}(1)-\mathrm{Br}(3), 2.4624(9) ; \operatorname{Pt}(1)-\mathrm{Br}(2), 2.4636(10) ; \mathrm{C}(1)-\operatorname{Pt}(1)-\mathrm{N}(1)$, 80.3(3); N(1)-Pt(1)-N(2), 96.2(3); C(1)-Pt(1)-Br(1), 94.5(3); N(2)-Pt(1)-Br(1), 89.07(19); C(1)$\mathrm{Pt}(1)-\mathrm{Br}(3), 89.8(2) ; \mathrm{N}(1)-\operatorname{Pt}(1)-\mathrm{Br}(3), 88.1(2) ; \mathrm{N}(2)-\operatorname{Pt}(1)-\mathrm{Br}(3), 91.9(2) ; \operatorname{Br}(1)-\operatorname{Pt}(1)-\operatorname{Br}(3)$, 91.90(3); $\mathrm{C}(1)-\mathrm{Pt}(1)-\mathrm{Br}(2), 84.6(2) ; \mathrm{N}(1)-\operatorname{Pt}(1)-\mathrm{Br}(2), 89.0(2) ; \mathrm{N}(2)-\operatorname{Pt}(1)-\operatorname{Br}(2), 93.6(2) ; \operatorname{Br}(1)-$ $\operatorname{Pt}(1)-\operatorname{Br}(2), 90.58(4)$. 
Figures S5 and S6 show the packing arrangement for $\mathbf{3 b}$ and $\mathbf{4 b}$, respectively. For $\mathbf{3 b}$, intramolecular short contacts $\mathrm{C}-\mathrm{F} \cdots \mathrm{Br}-\mathrm{Pt}$ and $\mathrm{C}-\mathrm{F} \cdots \mathrm{H}_{3} \mathrm{CN}$ are observed $(\mathrm{d}(\mathrm{F} \cdots \mathrm{Br})=$ $3.176 \AA$ and $\mathrm{d}(\mathrm{F} \cdots \mathrm{H})=2.509 \AA$ A $)$. In addition, bromido ligands display intramolecular interactions with aromatic and methyl protons $(\mathrm{d}(\mathrm{Br} \cdots \mathrm{H})=2.959 \AA$ and $3.115 \AA$, respectively). Analogous interactions of bromido ligands and aromatic and methylene protons are observed for $\mathbf{4 b}(\mathrm{d}(\mathrm{Br} \cdots \mathrm{H})=2.933 \AA$ and $2.930 \AA$, respectively). For $\mathbf{4 b}$, the fluoro substituent is not involved in intramolecular interactions while the axial bromido ligands lead to short contacts $(\mathrm{d}(\mathrm{Br} \cdots \mathrm{Br})=3.674 \AA)$.

\section{Absorption and emission spectroscopy}

Absorption and emission spectra of all the compounds were recorded in $10^{-4} \mathrm{M}$ dichloromethane solutions at 298K. The results are summarized in Tables 2 and 3.

Table 2. Absorption and emission data of compounds $\mathbf{L}, \mathbf{1}, \mathbf{I}$ and $\mathbf{2}$.

\begin{tabular}{|c|c|c|c|}
\hline Compound & $\begin{array}{l}\text { Absorption } \\
\lambda_{\max } / \mathbf{n m} \\
\left(\varepsilon / \mathbf{M}^{-1} \mathbf{c m}^{-1}\right)\end{array}$ & $\begin{array}{c}\text { Emission } \\
\mathrm{CH}_{2} \mathrm{Cl}_{2} \\
298 \mathrm{~K} \\
\lambda_{\max } / \mathrm{nm}\end{array}$ & $\phi$ \\
\hline $\mathbf{L}$ & $\begin{array}{c}276(1506), 286 \\
(1060)\end{array}$ & 350 & $0.074^{\mathrm{a}}$ \\
\hline & 285 (6548), 319 & 345 & $0.044^{\mathrm{a}}$ \\
\hline 1 & $\begin{array}{c}(3158), 364(3104), \\
391(2853)\end{array}$ & 574,619 & $0.001^{b}$ \\
\hline \multirow{2}{*}{$2 \mathbf{a}$} & 285 (3443), 311 & 347 & $0.056^{\mathrm{a}}$ \\
\hline & $\begin{array}{c}(2563), 35 /(238 /) \\
374(2618)\end{array}$ & 577,620 & $0.003^{b}$ \\
\hline
\end{tabular}




\begin{tabular}{|c|c|c|c|}
\hline Ib & $\begin{array}{c}296(7941), 336 \\
\text { (3239) }\end{array}$ & 349 & $0.016^{\mathrm{a}}$ \\
\hline \multirow{2}{*}{$2 \mathbf{b}$} & 288 (4524), 318 & 349 & $0.044^{\mathrm{a}}$ \\
\hline & $\begin{array}{c}(2713), 357(2140), \\
378(2618)\end{array}$ & 576,622 & $\mathrm{XXXX}$ \\
\hline Ic & $\begin{array}{c}300(6520), 375 \\
(3078)\end{array}$ & 344 & $0.014^{\mathrm{a}}$ \\
\hline $2 c$ & $\begin{array}{c}295(4194), 325 \\
(2857), 386(2731)\end{array}$ & 356 & $0.045^{\mathrm{a}}$ \\
\hline
\end{tabular}

${ }^{a}$ Quantum yields for emission in solution referred to naphthalene in cyclohexane. ${ }^{\mathrm{b}}$ Quantum yields for emission in solution referred to $\left[\mathrm{Ru}(\text { bipy })_{3}\right] \mathrm{Cl}_{3}$ in $\mathrm{H}_{2} \mathrm{O}$.

Table 3. Absorption and emission data of compounds 3 and 4.

\begin{tabular}{|c|c|c|c|}
\hline Compound & $\begin{array}{l}\text { Absorption } \\
\lambda_{\max } / \mathbf{n m} \\
\left(\varepsilon / \mathbf{M}^{-1} \mathbf{c m}^{-1}\right)\end{array}$ & $\begin{array}{c}\text { Emission } \\
\mathrm{CH}_{2} \mathrm{Cl}_{2} \\
298 \mathrm{~K} \\
\lambda_{\max } / \mathrm{nm}\end{array}$ & $\phi^{\mathrm{a}}$ \\
\hline $3 \mathbf{a}$ & 274 (4929) & 348 & 0.051 \\
\hline $\mathbf{3 b}$ & 274 (8094) & 351 & 0.064 \\
\hline $3 c$ & $\begin{array}{c}267(24526), 360 \\
(1509)\end{array}$ & $\mathrm{b}$ & $\mathrm{c}$ \\
\hline $4 a$ & $287(3831)$ & 349 & 0.051 \\
\hline $4 b$ & $286(6353)$ & 350 & 0.056 \\
\hline $4 c$ & $\begin{array}{c}271(23289), 379 \\
(3449), 450(3286)\end{array}$ & $\mathrm{b}$ & $\mathrm{c}$ \\
\hline
\end{tabular}

${ }^{a}$ Quantum yields for emission in solution referred to naphthalene in cyclohexane. ${ }^{b}$ Not observed.

${ }^{\mathrm{c}}$ Not determined. 
The absorption spectra of cyclometallated platinum(II) compounds show several bands in the UV-Visible range with moderate $\varepsilon$ values (Figure S7). The lowest energy band in the range 357-391 $\mathrm{nm}$ with extinction coefficients between 2100 and $3100 \mathrm{M}^{-1} \mathrm{~cm}^{-1}$ can be attributed to $\operatorname{Pt}(5 \mathrm{~d}) \rightarrow \pi^{*}(\mathrm{~L})$ metal-to-ligand charge transfer (MLCT) mixed with intraligand transitions. ${ }^{11,25-29}$ A higher energy absorption band is also observed in the 285-300 nm range with higher $\varepsilon$ values which is also recorded for the uncoordinated ligand $\mathbf{L}$ (Figure S8) and for this reason, it can be assigned to $\pi-\pi^{*}$ intraligand transitions.

Platinum(IV) complexes absorption spectra only show bands in the UV-Visible range between 267 and $290 \mathrm{~nm}$. The metal loses electron density with the oxidation of platinum and the MLCT transitions previously observed in their analogous platinum(II) complexes disappear $^{30}$ being the transition assigned as a intraligand charge transfer (ILCT) within the cyclometalated ligands. ${ }^{31}$ Only compounds $\mathbf{3 c}$ and $\mathbf{4 c}$ show additional absorption bands in the 360-450 $\mathrm{nm}$ range (Figure S9). According to the literature, due to the significant $\pi$-donating ability of the iodido ligand, the possible origin of this band is ligand-to-ligand charge transfer (LLCT, $\mathrm{I}^{-} \rightarrow \pi^{*}(\mathrm{~L})$ ) or ligand-to-metal charge transfer $\left(\mathrm{LMCT} \mathrm{I}^{-} \rightarrow \mathrm{d} \sigma^{*}(\mathrm{Pt})\right)$ transitions. $^{9}$

All compounds, except 3c and 4c, display a broad emission band in the 340-360 $\mathrm{nm}$ range when excited at the highest energy band (Figure 5 and figures S10-S12). This band matches the emission of the free ligand $\mathbf{L}$, shown in figure $\mathbf{S 1 3}$, when excited at the same wavelength and therefore, this emission could be attributed to intraligand $\left({ }^{1} \mathrm{IL}\right)$ transitions perturbed by the Pt center. ${ }^{29,32}$

Higher emission intensity was found for ligand $\mathbf{L}$ with respect to its complexes. This may be due to the metal orbital contribution to the emitting excited state of the complexes, with a MLCT character, which causes a reduction in the radiative rate constant, $\mathrm{k}_{\mathrm{r}} \cdot{ }^{31,33}$ 
As previously observed, ${ }^{11}$ the platinum(II) compound with chlorido as an ancillary ligand (2a) displays the most intense emission, among the studied cyclometallated platinum(II) compounds.

Coordination compounds Ib and Ic, in which the ligand act as [N,N']-chelate, show a lower emission intensity when compared to the corresponding [C,N,N'] cyclometallated platinum(II) analogues $\mathbf{2 b}$ and $\mathbf{2 c}$, respectively.

Compounds 1, 2a and $\mathbf{2 b}$ display an additional well-resolved band centred at $c a .620 \mathrm{~nm}$ when excited at the lowest energy absorption band (Figure S14). The vibronic structure of the band with progressional spacings of $1200 \mathrm{~cm}^{-1}$, typical of $\mathrm{v}(\mathrm{C}=\mathrm{C})$ and $\mathrm{v}(\mathrm{C}=\mathrm{N})$ stretching frequencies in the excited state, demonstrates the involvement of ligand

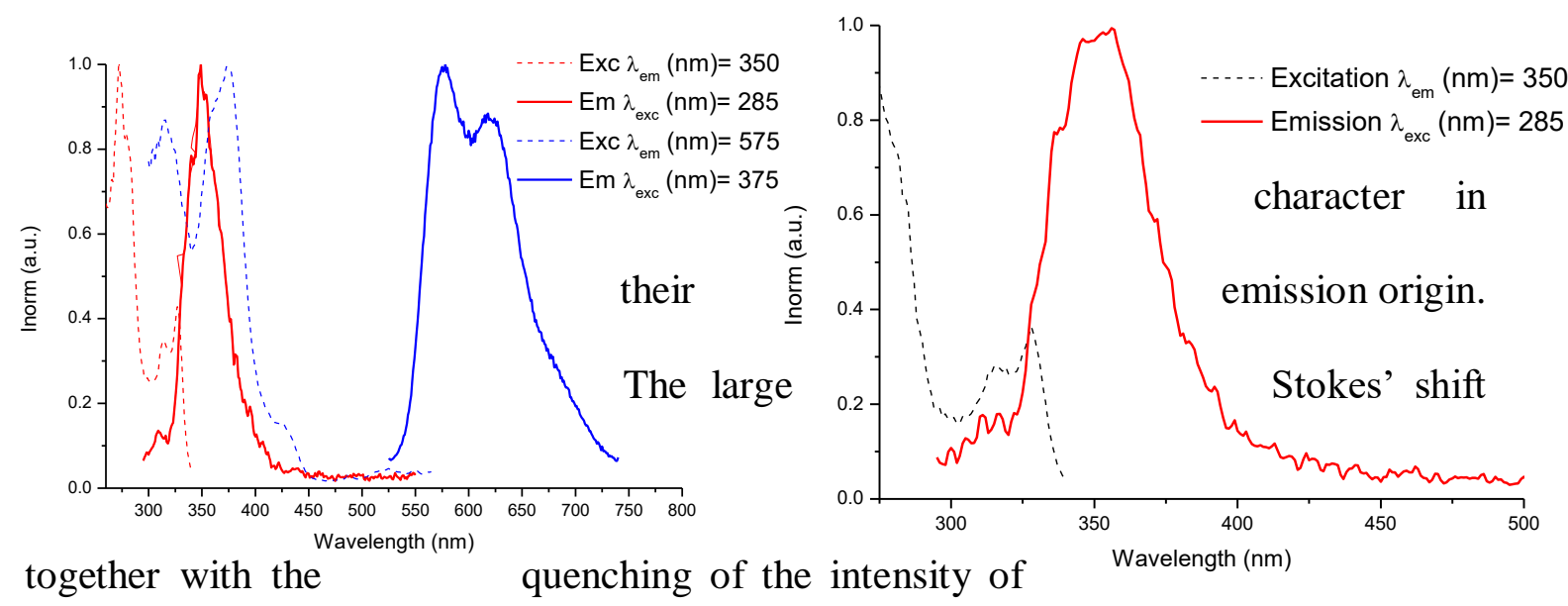

the band by the presence of oxygen (Figure S15) indicates phosphorescence ${ }^{3}$ IL emission.

Figure 5: Excitation and emission spectra of compounds $\mathbf{2 b}$ (left) and $\mathbf{4 b}$ (right) in dichloromethane solution at $298 \mathrm{~K}$. 
Higher emission intensity was recorded, in general, for platinum(IV) with corresponding higher emission quantum yields about 5\%, as previously observed in other cyclometallated platinum complexes. ${ }^{34}$ Similar quantum yield value was also recorded for $\mathrm{Pt}(\mathrm{II})$ complex $\mathbf{2 a}$, ascribed to the presence of a chlorido ancillary ligand according to previous data. ${ }^{11}$ On the contrary, no significant emission was displayed by iodine derivatives, probably due to iodido heavy atom quenching. ${ }^{35}$

\section{CONCLUSIONS}

The synthesis of [N,N']-chelate (Ib and Ic), [C,N,N']-cyclometallated platinum(II) (1, 2a-2c) and [C,N,N']-cyclometallated platinum(IV) compounds (3a-3c and 4a-4c) was achieved. All the compounds were fully characterised including X ray crystal structure determination of the compounds containing bromido ligands $\mathbf{I b}, \mathbf{2 b}, \mathbf{3 b}$ and $\mathbf{4 b}$. The analyses of these structures indicate than in all cases the molecules are held together by van der Waals interactions only.

The electronic absorption and emission properties of these compounds were investigated. The cyclometallated platinum(II) compounds $\mathbf{1}, \mathbf{2 a}, \mathbf{2 b}$, and $\mathbf{2 c}$ are emissive in the 340$360 \mathrm{~nm}$ range when excited at the highest energy band (285-295 $\mathrm{nm}$ ) observed in the absorption spectra, and this emission can be attributed to intraligand transitions. Noncyclometallated platinum(II) compounds Ib and Ic are also emissive in this region although with a lower intensity. Compounds $\mathbf{1}$ and 2a also emit at about $620 \mathrm{~nm}$ when excited at the lowest energy absorption band (357-391 nm) attributed to $\operatorname{Pt}(5 \mathrm{~d}) \rightarrow \mathrm{p}^{*}(\mathrm{~L})$ MLCT transition.

The platinum(IV) compounds $\mathbf{3 a}, \mathbf{3 b}, \mathbf{4 a}$, and $\mathbf{4 b}$ arising from oxidative addition of chlorine or bromine are emissive in the $300-400 \mathrm{~nm}$ range when excited at the highest energy absorption band, but compounds $\mathbf{3 c}$ and $\mathbf{4 c}$, arising from oxidative addition of 
iodine are not emissive probably due to the presence of iodido ligands. In particular, for the compounds containing bromido ligands the intensity of the emission follows the trend Ib $<\mathbf{2} \mathbf{b}<\mathbf{4} \mathbf{b}<\mathbf{3 b}$, which indicates that the emission is enhanced for cyclometallated versus non-cyclometallated compounds and for platinum(IV) versus platinum(II) compounds. The lower emission intensity observed for $\mathbf{4 b}$, containing three bromido ligands, than for $\mathbf{3 b}$, containing two bromido ligands, and the lack of emission of compounds $3 \mathbf{c}$ and $4 \mathbf{c}$ containing iodido ligands could be related with the heavy atom effect. As a whole, the results obtained in this work indicate that bromido ligands are a good choice to enhance the luminescence of cyclometallated platinum(IV) compounds and that tuning the nature and number of the halido ligands could be a good strategy to modulate the emission of these compounds.

\section{EXPERIMENTAL SECTION}

\section{General}

Microanalyses were performed at the Centres Científics i Tecnològics (Universitat de Barcelona) using a Carlo Erba model EA1108 elemental analyser. Electrospray mass spectra were performed at the Unitat d'Espectrometria de Masses (Universitat de Barcelona) in a LC/MSD-TOF spectrometer using $\mathrm{H}_{2} \mathrm{O}-\mathrm{CH}_{3} \mathrm{CN}$ 1:1 to introduce the sample. NMR spectra were recorded in $\mathrm{CDCl}_{3}$ at the Unitat d'RMN of the Universitat de Barcelona with a Mercury 400 spectrometer $\left({ }^{1} \mathrm{H}, 400 \mathrm{MHz} ;{ }^{19} \mathrm{~F}, 376.5 \mathrm{MHz}\right)$. Chemical shifts are given in $\delta$ values (ppm) relative to TMS $\left({ }^{1} \mathrm{H}\right)$ or $\mathrm{CFCl}_{3}\left({ }^{19} \mathrm{~F}\right)$ and coupling constants $\mathrm{J}$ are given in Hz. Multiplicity is expressed as: $\mathrm{s}$ (singlet), $\mathrm{d}$ (doublet), $\mathrm{t}$ (triplet), $q$ (quadruplet), qi (quintuplet) and m (multiplet). Numbering schemes for the compounds characterized are displayed in Schemes 1 and 2. UV/Vis spectra were recorded in $\mathrm{CH}_{2} \mathrm{Cl}_{2}$ with a Cary 100 scan 388 Varian UV spectrometer. Emission and excitation spectra were 
recorded in a Horiba Jobin-Yvon SPEX Nanolog-TM spectrofluorimeter at $298 \mathrm{~K}$ using $10^{-4} \mathrm{M}$ solutions. Total luminescence quantum yields were measured at $298 \mathrm{~K}$ relative to $\left[\mathrm{Ru}(\text { bipy })_{3}\right] \mathrm{Cl}_{2}$ in water $(\phi=0.042)$ and naphthalene in cyclohexane $(\phi=0.23)$ as standard references.

\section{Preparation of the complexes}

All reagents were obtained from commercial sources and used as received. Ligand 4$\mathrm{FC}_{6} \mathrm{H}_{4} \mathrm{CHN}\left(\mathrm{CH}_{2}\right)_{3} \mathrm{~N}\left(\mathrm{CH}_{3}\right)_{2}$ (L) ${ }^{11}$, reagent $\mathrm{PhICl}_{2}{ }^{18}$ and platinum compounds cis$\left[\mathrm{PtBr}_{2}(\mathrm{dmso})_{2}\right] \quad(\mathbf{B}),{ }^{36} \quad c i s-\left[\mathrm{PtI}_{2}(\mathrm{dmso})_{2}\right] \quad$ (C), ${ }^{36} \quad\left[\mathrm{Pt}\left(\mathrm{CH}_{3}\right)\left\{\left(\mathrm{CH}_{3}\right)_{2} \mathrm{~N}\left(\mathrm{CH}_{2}\right)_{3} \mathrm{~N}=\mathrm{CH}(4-\right.\right.$ $\left.\left.\left.\mathrm{FC}_{6} \mathrm{H}_{3}\right)\right\}\right] \quad(\mathbf{1}),{ }^{11} \quad\left[\mathrm{PtCl}\left\{\left(\mathrm{CH}_{3}\right)_{2} \mathrm{~N}\left(\mathrm{CH}_{2}\right)_{3} \mathrm{~N}=\mathrm{CH}\left(4-\mathrm{FC}_{6} \mathrm{H}_{3}\right)\right\}\right] \quad(\mathbf{2 a})^{11} \quad$ and $\left[\mathrm{PtCl}_{3}\left\{\left(\mathrm{CH}_{3}\right)_{2} \mathrm{~N}\left(\mathrm{CH}_{2}\right)_{3} \mathrm{~N}=\mathrm{CH}\left(4-\mathrm{FC}_{6} \mathrm{H}_{3}\right)\right\}\right] \quad(\mathbf{4 a})^{37}$ were prepared as reported elsewhere. $\left[\operatorname{PtBr}_{2}\left\{\left(\mathrm{CH}_{3}\right)_{2} \mathbf{N}\left(\mathrm{CH}_{2}\right)_{3} \mathbf{N}=\mathbf{C H}\left(4-\mathbf{F C}_{6} \mathbf{H}_{4}\right)\right\}\right](\mathbf{I b})$ was obtained from the reaction of 0.405 $\mathrm{g}(0.797 \mathrm{mmols})$ of $\left[\mathrm{PtBr}_{2}(\mathrm{dmso})_{2}\right](\mathbf{B})$ and $0.177 \mathrm{~g}(0.850 \mathrm{mmols})$ of $\mathbf{L}$ in $25 \mathrm{ml}$ of dry methanol. The mixture was refluxed at $65^{\circ} \mathrm{C}$ for 4 hours. Half of the volume was removed under vacuum and the solution was left to crystallise in the freezer. The yellow solid was filtered and dried under vacuum. Yield: $0.25 \mathrm{~g}(56 \%){ }^{1} \mathbf{H} \mathbf{~ N M R}\left(\mathrm{CDCl}_{3}, 400 \mathrm{MHz}\right): \delta$ $9.38\left[\mathrm{~m}, 2 \mathrm{H}, \mathrm{H}^{\mathrm{a}}\right] ; 8.43\left[\mathrm{~s}, 1 \mathrm{H},{ }^{3} \mathrm{~J}(\mathrm{Pt}-\mathrm{H})=115.6, \mathrm{H}^{\mathrm{d}}\right] ; 7.27\left[\mathrm{t}, 2 \mathrm{H},{ }^{3} \mathrm{~J}(\mathrm{~F}-\mathrm{H})=8.0, \mathrm{H}^{\mathrm{b}}\right] ;\{4.93$ $\left.[\mathrm{m}, 1 \mathrm{H}] ; 4.11[\mathrm{~m}, 1 \mathrm{H}] ; 3.49[\mathrm{~m}, 1 \mathrm{H}] ; 2.62[\mathrm{~m}, 1 \mathrm{H}] ; 2.17[\mathrm{~m}, 1 \mathrm{H}] ; 1.99[\mathrm{~m}, 1 \mathrm{H}], \mathrm{H}^{\mathrm{e}, \mathrm{f} g}\right\}$; $\left\{2.95[\mathrm{~s}, 3 \mathrm{H}] ; 2.85[\mathrm{~s}, 3 \mathrm{H}], \mathrm{H}^{\mathrm{h}}\right\}{ }^{\mathbf{1 9}} \mathbf{F}$ NMR $\left(\mathrm{CDCl}_{3}, 376.5 \mathrm{MHz}\right): \delta-101.50[\mathrm{~m}, 1 \mathrm{~F}] . \mathbf{M S}-$ ESI $^{+}: \mathrm{m} / \mathrm{z} 483.02[\mathrm{M}-\mathrm{Br}]^{+}$. Anal. Found (calcd for $\mathrm{C}_{12} \mathrm{H}_{17} \mathrm{Br}_{2} \mathrm{FN}_{2} \mathrm{Pt}$ ): C, 26.27 (25.59); H, 3.23 (3.04); N, 5.01 (4.97).

$\left[\operatorname{PtI}_{2}\left\{\left(\mathrm{CH}_{3}\right)_{2} \mathbf{N}\left(\mathrm{CH}_{2}\right)_{3} \mathbf{N}=\mathbf{C H}\left(4-\mathbf{F C}_{6} \mathbf{H}_{4}\right)\right\}\right](\mathrm{Ic})$ was obtained from the reaction of $0.225 \mathrm{~g}$ $(0.372 \mathrm{mmols})$ of $\left[\mathrm{PtI}_{2}(\mathrm{dmso})_{2}\right](\mathbf{C})$ and $0.082 \mathrm{~g}(0.394 \mathrm{mmols})$ of $\mathbf{L}$ in $25 \mathrm{ml}$ of dry methanol. A brown solid was obtained following the same procedure used for Ib. Yield: 
$0.10 \mathrm{~g}(41 \%) .{ }^{1} \mathbf{H} \mathbf{N M R}\left(\mathrm{CDCl}_{3}, 400 \mathrm{MHz}\right): \delta 9.45\left[\mathrm{~m}, 2 \mathrm{H}, \mathrm{H}^{\mathrm{a}}\right] ; 8.47\left[\mathrm{~s}, 1 \mathrm{H},{ }^{3} \mathrm{~J}(\mathrm{Pt}-\mathrm{H})=\right.$ 115.6, $\left.\mathrm{H}^{\mathrm{d}}\right] ; 7.25\left[\mathrm{t}, 2 \mathrm{H},{ }^{3} \mathrm{~J}(\mathrm{~F}-\mathrm{H})=8.0, \mathrm{H}^{\mathrm{b}}\right] ;\{4.95[\mathrm{~m}, 1 \mathrm{H}] ; 4.13[\mathrm{~m}, 1 \mathrm{H}] ; 3.23[\mathrm{~m}, 1 \mathrm{H}]$; $\left.2.72[\mathrm{~m}, 1 \mathrm{H}] ; 2.50[\mathrm{~m}, 1 \mathrm{H}] ; 1.97[\mathrm{~m}, 1 \mathrm{H}], \mathrm{H}^{\mathrm{e}, \mathrm{f}, \mathrm{g}}\right\} ;\left\{2.97[\mathrm{~s}, 3 \mathrm{H}] ; 2.84[\mathrm{~s}, 3 \mathrm{H}], \mathrm{H}^{\mathrm{h}}\right\}{ }^{19} \mathbf{F}$ NMR $\left(\mathrm{CDCl}_{3}, 376.5 \mathrm{MHz}\right): \delta-101.50[\mathrm{~m}, 1 \mathrm{~F}]$. MS-ESI $^{+}: \mathrm{m} / \mathrm{z} 530.00[\mathrm{M}-\mathrm{I}]^{+}$. Anal. Found (calcd for $\mathrm{C}_{12} \mathrm{H}_{17} \mathrm{I}_{2} \mathrm{FN} 2 \mathrm{Pt}$ ): C, 21.56 (21.93); H, 2.67 (2.61); N, 4.07 (4.26).

$\left[\operatorname{PtBr}\left\{\left(\mathrm{CH}_{3}\right)_{2} \mathbf{N}\left(\mathrm{CH}_{2}\right)_{3} \mathbf{N}=\mathbf{C H}\left(4-\mathbf{F C}_{6} \mathbf{H}_{3}\right)\right\}\right]$ (2b) was obtained from the reaction of 0.102 g (0.233 mmols) of $\left[\mathrm{PtCl}\left\{\left(\mathrm{CH}_{3}\right)_{2} \mathrm{~N}\left(\mathrm{CH}_{2}\right)_{3} \mathrm{~N}=\mathrm{CH}\left(4-\mathrm{FC}_{6} \mathrm{H}_{3}\right)\right\}\right]$ (2a) and $0.116 \mathrm{~g}(0.975$ mmols) of $\mathrm{KBr}$ in $10 \mathrm{ml}$ of dry methanol. The mixture was refluxed at $65{ }^{\circ} \mathrm{C}$ for 48 hours and the solvent was removed under vacuum. The residue was extracted with $10 \mathrm{ml}$ of $\mathrm{CH}_{2} \mathrm{Cl}_{2}$ and $10 \mathrm{ml}$ of methanol were added. Half of the volume was removed under vacuum and the solution was left to crystallise in the freezer. The orange solid was filtered and dried under vacuum. Yield: $0.039 \mathrm{~g}(35 \%) .{ }^{\mathbf{1}} \mathbf{H} \mathbf{~ N M R}\left(\mathrm{CDCl}_{3}, 400 \mathrm{MHz}\right): \delta 8.33$ [t, $\left.1 \mathrm{H},{ }^{4} \mathrm{~J}(\mathrm{H}-\mathrm{H})=1.5,{ }^{3} \mathrm{~J}(\mathrm{Pt}-\mathrm{H})=143.7, \mathrm{H}^{\mathrm{d}}\right] ; 8.00\left[\mathrm{dd}, 1 \mathrm{H},{ }^{3} \mathrm{~J}(\mathrm{~F}-\mathrm{H})=10.7,{ }^{4} \mathrm{~J}(\mathrm{H}-\mathrm{H})=2.5\right.$, $\left.{ }^{3} \mathrm{~J}(\mathrm{Pt}-\mathrm{H})=46.6, \mathrm{H}^{\mathrm{a}}\right] ; 7.26\left[\mathrm{~m}, 1 \mathrm{H}, \mathrm{H}^{\mathrm{c}}\right] ; 6.68\left[\mathrm{td}, 1 \mathrm{H},{ }^{3} \mathrm{~J}(\mathrm{~F}-\mathrm{H})={ }^{3} \mathrm{~J}(\mathrm{H}-\mathrm{H})=8.5,{ }^{4} \mathrm{~J}(\mathrm{H}-\mathrm{H})=\right.$ $\left.2.5, \mathrm{H}^{\mathrm{b}}\right] ; 3.86\left[\mathrm{t}, 2 \mathrm{H},{ }^{3} \mathrm{~J}(\mathrm{H}-\mathrm{H})=5.1,{ }^{3} \mathrm{~J}(\mathrm{Pt}-\mathrm{H})=35.2, \mathrm{H}^{\mathrm{e}}\right] ; 2.86\left[\mathrm{~m}, 8 \mathrm{H}, \mathrm{H}^{\mathrm{g}, \mathrm{h}}\right] ; 2.03[\mathrm{qi}, 2 \mathrm{H}$, $\left.{ }^{3} \mathrm{~J}(\mathrm{H}-\mathrm{H})=5.6, \mathrm{H}^{\mathrm{f}}\right] .{ }^{19} \mathbf{F}$ NMR $\left(\mathrm{CDCl}_{3}, 376.5 \mathrm{MHz}\right): \delta-103.85[\mathrm{~m}, 1 \mathrm{~F}] . \mathbf{M S}-\mathbf{E S I} \mathbf{I}^{+}: \mathrm{m} / \mathrm{z}$ $438.02[\mathrm{M}+\mathrm{H}]^{+} ; 402.10[\mathrm{M}-\mathrm{Br}]^{+}$. Anal. Found (calcd for $\mathrm{C}_{12} \mathrm{H}_{16} \mathrm{BrFN}_{2} \mathrm{Pt}$ ): $\mathrm{C}, 30.00$ (29.89); H, 3.45 (3.34); N, 5.70 (5.81).

$\left[\operatorname{PtI}\left\{\left(\mathrm{CH}_{3}\right)_{2} \mathbf{N}\left(\mathrm{CH}_{2}\right)_{3} \mathbf{N}=\mathbf{C H}\left(4-\mathbf{F C}_{6} \mathbf{H}_{3}\right)\right\}\right](\mathbf{2 c})$ was obtained from the reaction of $0.306 \mathrm{~g}$ $(0.504$ mmols $) \quad$ of $\quad$ cis- $\left[\mathrm{PtI}_{2}(\mathrm{dmso})_{2}\right] \quad(\mathbf{C}), \quad 0.133 \quad \mathrm{~g} \quad(0.639 \quad \mathrm{mmols})$ of 4 $\mathrm{FC}_{6} \mathrm{H}_{4} \mathrm{CH}=\mathrm{N}\left(\mathrm{CH}_{2}\right)_{3} \mathrm{~N}\left(\mathrm{CH}_{3}\right)_{2}(\mathbf{L})$ and $0.053 \mathrm{~g}(0.646 \mathrm{mmols})$ of anhydrous sodium acetate in $50 \mathrm{ml}$ of dry methanol. The mixture was refluxed at $65{ }^{\circ} \mathrm{C}$ for 72 hours and the solvent was removed under vacuum. The residue was extracted with $10 \mathrm{ml}$ of $\mathrm{CH}_{2} \mathrm{Cl}_{2}$ and $10 \mathrm{ml}$ of methanol were added. Half of the volume was removed under vacuum and the solution was left to crystallise in the freezer. The red solid was filtered and dried under vacuum. 
Yield: $0.081 \mathrm{~g} \mathrm{(30 \% ).}{ }^{\mathbf{1}} \mathbf{H}$ NMR $\left(\mathrm{CDCl}_{3}, 400 \mathrm{MHz}\right): \delta 8.45\left[\mathrm{dd}, 1 \mathrm{H},{ }^{3} \mathrm{~J}(\mathrm{~F}-\mathrm{H})=11.4,{ }^{4} \mathrm{~J}(\mathrm{H}-\right.$ $\left.\mathrm{H})=2.5,{ }^{3} \mathrm{~J}(\mathrm{Pt}-\mathrm{H})=39.8, \mathrm{H}^{\mathrm{a}}\right] ; 8.38\left[\mathrm{t}, 1 \mathrm{H},{ }^{4} \mathrm{~J}(\mathrm{H}-\mathrm{H})=1.7,{ }^{3} \mathrm{~J}(\mathrm{Pt}-\mathrm{H})=135.8, \mathrm{H}^{\mathrm{d}}\right] ; 7.26[\mathrm{~m}$, $\left.1 \mathrm{H}, \mathrm{H}^{\mathrm{c}}\right] ; 6.65\left[\mathrm{td}, 1 \mathrm{H},{ }^{3} \mathrm{~J}(\mathrm{~F}-\mathrm{H})={ }^{3} \mathrm{~J}(\mathrm{H}-\mathrm{H})=8.4,{ }^{4} \mathrm{~J}(\mathrm{H}-\mathrm{H})=2.6, \mathrm{H}^{\mathrm{b}}\right] ; 3.83\left[\mathrm{t}, 2 \mathrm{H},{ }^{3} \mathrm{~J}(\mathrm{H}-\mathrm{H})=\right.$ 5.6, $\left.\mathrm{H}^{\mathrm{e}}\right] ; 3.01\left[\mathrm{~s}, 6 \mathrm{H},{ }^{3} \mathrm{~J}(\mathrm{Pt}-\mathrm{H})=16.7, \mathrm{H}^{\mathrm{h}}\right] ; 2.81\left[\mathrm{~m}, 2 \mathrm{H}, \mathrm{H}^{\mathrm{g}}\right] ; 2.05\left[\mathrm{qi}, 2 \mathrm{H},{ }^{3} \mathrm{~J}(\mathrm{H}-\mathrm{H})=5.7\right.$, $\left.\mathrm{H}^{\mathrm{f}}\right] .{ }^{19} \mathbf{F}$ NMR $\left(\mathrm{CDCl}_{3}, 376.5 \mathrm{MHz}\right): \delta-103.71[\mathrm{~m}, 1 \mathrm{~F}] . \mathbf{M S}-\mathbf{E S I} \mathbf{I}^{+}: \mathrm{m} / \mathrm{z} 530.01[\mathrm{M}+\mathrm{H}]^{+}$; $443.12\left[\mathrm{M}-\mathrm{I}+\mathrm{CH}_{3} \mathrm{CN}\right]^{+} ; 401.09[\mathrm{M}-\mathrm{I}]^{+} ; 402.09[\mathrm{M}-\mathrm{I}]^{+}$. Anal. Found (calcd for $\left.\mathrm{C}_{12} \mathrm{H}_{16} \mathrm{IFN}_{2} \mathrm{Pt}\right)$ : C, 27.08 (27.23); H, 3.13 (3.05); N, 5.23 (5.29).

$\left[\operatorname{Pt}\left(\mathrm{CH}_{3}\right) \mathrm{Cl}_{2}\left\{\left(\mathrm{CH}_{3}\right)_{2} \mathbf{N}\left(\mathrm{CH}_{2}\right)_{3} \mathbf{N}=\mathbf{C H}\left(4-\mathrm{FC}_{6} \mathrm{H}_{3}\right)\right\}\right]$ (3a) was obtained from the reaction of $0.076 \mathrm{~g}$ (0.182 mmols) of $\left[\mathrm{Pt}\left(\mathrm{CH}_{3}\right)\left\{\left(\mathrm{CH}_{3}\right)_{2} \mathrm{~N}\left(\mathrm{CH}_{2}\right)_{3} \mathrm{~N}=\mathrm{CH}\left(4-\mathrm{FC}_{6} \mathrm{H}_{3}\right)\right\}\right]$ (1) and $0.051 \mathrm{~g}$ ( $0.185 \mathrm{mmols})$ of iodobenzene dichloride in $8 \mathrm{ml}$ of acetone. The mixture was stirred at room temperature for 1 hour and the solvent was removed under vacuum. The residue was treated with diethyl ether and the yellow solid was filtered and dried under vacuum. Yield: $0.071 \mathrm{~g}(80 \%) .{ }^{1} \mathbf{H}$ NMR $\left(\mathrm{CDCl}_{3}, 400 \mathrm{MHz}\right): \delta 8.49\left[\mathrm{~s}, 1 \mathrm{H},{ }^{3} \mathrm{~J}(\mathrm{Pt}-\mathrm{H})=45.5, \mathrm{H}^{\mathrm{d}}\right]$; $7.43\left[\mathrm{dd}, 1 \mathrm{H},{ }^{3} \mathrm{~J}(\mathrm{H}-\mathrm{H})=8.3,{ }^{3} \mathrm{~J}(\mathrm{~F}-\mathrm{H})=5.6, \mathrm{H}^{\mathrm{c}}\right] ; 7.01\left[\mathrm{dd}, 1 \mathrm{H},{ }^{3} \mathrm{~J}(\mathrm{~F}-\mathrm{H})=8.9,{ }^{4} \mathrm{~J}(\mathrm{H}-\mathrm{H})=\right.$ $\left.2.4, \mathrm{H}^{\mathrm{a}}\right] ; 6.83\left[\mathrm{td}, 1 \mathrm{H},{ }^{3} \mathrm{~J}(\mathrm{~F}-\mathrm{H})={ }^{3} \mathrm{~J}(\mathrm{H}-\mathrm{H})=8.4,{ }^{4} \mathrm{~J}(\mathrm{H}-\mathrm{H})=2.4, \mathrm{H}^{\mathrm{b}}\right] ; 4.26\left[\mathrm{~m}, 1 \mathrm{H}, \mathrm{H}^{\mathrm{e}}\right] ; 3.90$ $\left[\mathrm{m}, 1 \mathrm{H}, \mathrm{H}^{\mathrm{e}}\right] ; 2.94\left[\mathrm{~m}, 2 \mathrm{H}, \mathrm{H}^{\mathrm{g}}\right] ; 2.65\left[\mathrm{~s}, 3 \mathrm{H}, \mathrm{H}^{\mathrm{h}}\right] ; 2.48\left[\mathrm{~s}, 3 \mathrm{H}, \mathrm{H}^{\mathrm{h}}\right] ; 2.27\left[\mathrm{~m}, 1 \mathrm{H}, \mathrm{H}^{\mathrm{f}}\right] ; 2.12$ $\left[\mathrm{m}, 1 \mathrm{H}, \mathrm{H}^{\mathrm{f}}\right] ; 1.80\left[\mathrm{~s}, 3 \mathrm{H},{ }^{2} \mathrm{~J}(\mathrm{Pt}-\mathrm{H})=59.6, \mathrm{H}^{\mathrm{i}}\right] .{ }^{19} \mathbf{F} \mathbf{N M R}\left(\mathrm{CDCl}_{3}, 376.5 \mathrm{MHz}\right): \delta-101.46$ [m, 1F]. MS-ESI ${ }^{+}:$m/z $494.11\left[\mathrm{M}-\mathrm{Cl}+\mathrm{CH}_{3} \mathrm{CN}\right]^{+} ; 453.09[\mathrm{M}-\mathrm{Cl}]^{+} ; 416.11[\mathrm{M}-2 \mathrm{Cl}-\mathrm{H}]^{+}$. Anal. Found (calcd for $\mathrm{C}_{13} \mathrm{H}_{19} \mathrm{Cl}_{2} \mathrm{FN}_{2} \mathrm{Pt} \cdot 2 \mathrm{H}_{2} \mathrm{O}$ ): C, 29.80 (29.78); H, 3.78 (4.42); N, 5.27 (5.34).

$\left[\operatorname{Pt}\left(\mathrm{CH}_{3}\right) \mathrm{Br}_{2}\left\{\left(\mathrm{CH}_{3}\right)_{2} \mathbf{N}\left(\mathrm{CH}_{2}\right)_{3} \mathbf{N}=\mathbf{C H}\left(4-\mathbf{F C}_{6} \mathbf{H}_{3}\right)\right\}\right](3 \mathrm{~b})$ was prepared as an orange solid by following the same method from $0.078 \mathrm{~g}(0.187 \mathrm{mmols})$ of compound 1 and $0.060 \mathrm{~g}$ (0.375 mmols) of $\mathrm{Br}_{2}$. Yield: $0.082 \mathrm{~g}(76 \%) .{ }^{1} \mathbf{H} \mathbf{N M R}\left(\mathrm{CDCl}_{3}, 400 \mathrm{MHz}\right): \delta 8.37[\mathrm{~s}, 1 \mathrm{H}$, $\left.{ }^{3} \mathrm{~J}(\mathrm{Pt}-\mathrm{H})=44.6, \mathrm{H}^{\mathrm{d}}\right] ; 7.43\left[\mathrm{dd}, 1 \mathrm{H},{ }^{3} \mathrm{~J}(\mathrm{H}-\mathrm{H})=8.3,{ }^{3} \mathrm{~J}(\mathrm{~F}-\mathrm{H})=5.8, \mathrm{H}^{\mathrm{c}}\right] ; 7.02\left[\mathrm{dd}, 1 \mathrm{H},{ }^{3} \mathrm{~J}(\mathrm{~F}-\right.$ $\left.\mathrm{H})=9.9,{ }^{4} \mathrm{~J}(\mathrm{H}-\mathrm{H})=2.3,{ }^{3} \mathrm{~J}(\mathrm{Pt}-\mathrm{H})=33.3, \mathrm{H}^{\mathrm{a}}\right] ; 6.76\left[\mathrm{td}, 1 \mathrm{H},{ }^{3} \mathrm{~J}(\mathrm{~F}-\mathrm{H})={ }^{3} \mathrm{~J}(\mathrm{H}-\mathrm{H})=8.5,{ }^{4} \mathrm{~J}(\mathrm{H}-\right.$ 
$\left.\mathrm{H})=2.4, \mathrm{H}^{\mathrm{b}}\right] ; 4.01\left[\mathrm{~m}, 2 \mathrm{H}, \mathrm{H}^{\mathrm{e}}\right] ; 2.98\left[\mathrm{~m}, 2 \mathrm{H}, \mathrm{H}^{\mathrm{g}}\right] ; 2.87\left[\mathrm{~s}, 6 \mathrm{H},{ }^{3} \mathrm{~J}(\mathrm{Pt}-\mathrm{H})=15.1, \mathrm{H}^{\mathrm{h}}\right] ; 2.21$ $\left[\mathrm{m}, 2 \mathrm{H}, \mathrm{H}^{\mathrm{f}}\right] ; 1.99\left[\mathrm{~s}, 3 \mathrm{H},{ }^{2} \mathrm{~J}(\mathrm{Pt}-\mathrm{H})=67.6, \mathrm{H}^{\mathrm{i}}\right] .{ }^{19} \mathbf{F} \mathbf{N M R}\left(\mathrm{CDCl}_{3}, 376.5 \mathrm{MHz}\right): \delta-102.43$ [m, 1F]. MS-ESI ${ }^{+}: \mathrm{m} / \mathrm{z} 538.06\left[\mathrm{M}-\mathrm{Br}+\mathrm{CH}_{3} \mathrm{CN}\right]^{+} ; 497.03[\mathrm{M}-\mathrm{Br}]^{+} ; 416.11[\mathrm{M}-2 \mathrm{Br}-$ $\mathrm{H}]^{+}$.Anal. Found (calcd for $\mathrm{C}_{13} \mathrm{H}_{19} \mathrm{Br}_{2} \mathrm{FN}_{2} \mathrm{Pt} \cdot \mathrm{H}_{2} \mathrm{O}$ ): C, 25.69 (26.23); H, 3.20 (3.19); N, $4.53(4.71)$

$\left[\operatorname{Pt}\left(\mathrm{CH}_{3}\right) \mathbf{I}_{2}\left\{\left(\mathrm{CH}_{3}\right)_{2} \mathbf{N}\left(\mathrm{CH}_{2}\right)_{3} \mathbf{N}=\mathbf{C H}\left(4-\mathbf{F C}_{6} \mathbf{H}_{3}\right)\right\}\right]$ (3c) was prepared as a dark brown solid by following the same method from $0.073 \mathrm{~g}(0.175 \mathrm{mmols})$ of compound 1 and $0.055 \mathrm{~g}$ (0.217 mmols) of $\mathrm{I}_{2}$. Yield: $0.061 \mathrm{~g}(52 \%) .{ }^{1} \mathbf{H} \mathbf{~ N M R}\left(\mathrm{CDCl}_{3}, 400 \mathrm{MHz}\right): \delta 8.21[\mathrm{t}, 1 \mathrm{H}$, $\left.{ }^{4} \mathrm{~J}(\mathrm{H}-\mathrm{H})=1.7,{ }^{3} \mathrm{~J}(\mathrm{Pt}-\mathrm{H})=47.2, \mathrm{H}^{\mathrm{d}}\right] ; 7.45\left[\mathrm{dd}, 1 \mathrm{H},{ }^{3} \mathrm{~J}(\mathrm{H}-\mathrm{H})=8.3,{ }^{3} \mathrm{~J}(\mathrm{~F}-\mathrm{H})=5.7, \mathrm{H}^{\mathrm{c}}\right] ; 7.02$ $\left.\left[\mathrm{dd}, 1 \mathrm{H},{ }^{3} \mathrm{~J}(\mathrm{~F}-\mathrm{H})=9.7,{ }^{4} \mathrm{~J}(\mathrm{H}-\mathrm{H})=2.4,{ }^{3} \mathrm{~J}(\mathrm{Pt}-\mathrm{H})=38.2, \mathrm{H}^{\mathrm{a}}\right]\right] ; 6.64\left[\mathrm{td}, 1 \mathrm{H},{ }^{3} \mathrm{~J}(\mathrm{~F}-\mathrm{H})={ }^{3} \mathrm{~J}(\mathrm{H}-\right.$ $\left.\mathrm{H})=8.5,{ }^{4} \mathrm{~J}(\mathrm{H}-\mathrm{H})=2.3, \mathrm{H}^{\mathrm{b}}\right] ; 4.06\left[\mathrm{t}, 2 \mathrm{H},{ }^{3} \mathrm{~J}(\mathrm{H}-\mathrm{H})=4.6, \mathrm{H}^{\mathrm{e}}\right] ; 3.18\left[\mathrm{~s}, 6 \mathrm{H},{ }^{3} \mathrm{~J}(\mathrm{Pt}-\mathrm{H})=17.4\right.$, $\left.\mathrm{H}^{\mathrm{h}}\right] ; 3.05\left[\mathrm{~m}, 2 \mathrm{H}, \mathrm{H}^{\mathrm{g}}\right] ; 2.26\left[\mathrm{~s}, 3 \mathrm{H},{ }^{2} \mathrm{~J}(\mathrm{Pt}-\mathrm{H})=68.3, \mathrm{H}^{\mathrm{i}}\right], 2.22\left[\mathrm{~m}, 2 \mathrm{H}, \mathrm{H}^{\mathrm{f}}\right] .{ }^{19} \mathbf{F}$ NMR $\left(\mathrm{CDCl}_{3}, 376.5 \mathrm{MHz}\right): \delta-102.63[\mathrm{~m}, 1 \mathrm{~F}]$. MS-ESI $^{+}: \mathrm{m} / \mathrm{z} 688.96\left[\mathrm{M}+\mathrm{NH}_{4}\right]^{+} ; 544.02[\mathrm{M}-$ $\mathrm{I}^{+} ; 415.11[\mathrm{M}-2 \mathrm{I}-\mathrm{H}]^{+}$. Anal. Found (calcd for $\left.\mathrm{C}_{13} \mathrm{H}_{19} \mathrm{I}_{2} \mathrm{FN}_{2} \mathrm{Pt} \cdot 1 / 2 \mathrm{I}_{2}\right)$ : C, 19.14 (19.56); H, $2.16(2.40) ; \mathrm{N}, 3.17(3.51)$.

$\left.\operatorname{PtBr}_{3}\left\{\left(\mathrm{CH}_{3}\right)_{2} \mathbf{N}\left(\mathrm{CH}_{2}\right)_{3} \mathbf{N}=\mathbf{C H}\left(4-\mathrm{FC}_{6} \mathrm{H}_{3}\right)\right\}\right]$ (4b) was prepared as a brown solid by following the same method from $0.029 \mathrm{~g} \quad(0.060$ mmols $)$ of $\left[\mathrm{PtBr}\left\{\left(\mathrm{CH}_{3}\right)_{2} \mathrm{~N}\left(\mathrm{CH}_{2}\right)_{3} \mathrm{~N}=\mathrm{CH}\left(4-\mathrm{FC}_{6} \mathrm{H}_{3}\right)\right\}\right](\mathbf{2 b})$ and $0.050 \mathrm{~g}(0.313$ mmols $)$ of $\mathrm{Br}_{2}$. Yield: $0.039 \mathrm{~g}(86 \%) .{ }^{1} \mathbf{H}$ NMR $\left(\mathrm{CDCl}_{3}, 400 \mathrm{MHz}\right): \delta 8.09\left[\mathrm{~s}, 1 \mathrm{H},{ }^{3} \mathrm{~J}(\mathrm{Pt}-\mathrm{H})=93.9, \mathrm{H}^{\mathrm{d}}\right] ; 7.97$ $\left[\mathrm{dd}, 1 \mathrm{H},{ }^{3} \mathrm{~J}(\mathrm{~F}-\mathrm{H})=9.5,{ }^{4} \mathrm{~J}(\mathrm{H}-\mathrm{H})=2.6, \mathrm{H}^{\mathrm{a}}\right] ; 7.52\left[\mathrm{dd}, 1 \mathrm{H},{ }^{3} \mathrm{~J}(\mathrm{H}-\mathrm{H})=8.9,{ }^{4} \mathrm{~J}(\mathrm{~F}-\mathrm{H})=5.4\right.$, $\left.\mathrm{H}^{\mathrm{c}}\right] ; 6.85\left[\mathrm{td}, 1 \mathrm{H},{ }^{3} \mathrm{~J}(\mathrm{~F}-\mathrm{H})={ }^{3} \mathrm{~J}(\mathrm{H}-\mathrm{H})=8.2,{ }^{4} \mathrm{~J}(\mathrm{H}-\mathrm{H})=2.1, \mathrm{H}^{\mathrm{b}}\right] ; 3.99\left[\mathrm{t}, 2 \mathrm{H},{ }^{3} \mathrm{~J}(\mathrm{H}-\mathrm{H})=5.1\right.$, $\left.\mathrm{H}^{\mathrm{e}}\right] ; 3.17\left[\mathrm{~s}, 6 \mathrm{H},{ }^{3} \mathrm{~J}(\mathrm{Pt}-\mathrm{H})=13.4, \mathrm{H}^{\mathrm{h}}\right] ; 2.94\left[\mathrm{~m}, 2 \mathrm{H}, \mathrm{H}^{\mathrm{g}}\right] ; 2.28\left[\mathrm{~m}, 2 \mathrm{H}, \mathrm{H}^{\mathrm{f}}\right] .{ }^{19} \mathbf{F} \mathbf{N M R}$ $\left(\mathrm{CDCl}_{3}, 376.5 \mathrm{MHz}\right): \delta-101.75[\mathrm{~m}, 1 \mathrm{~F}]$. MS-ESI $^{+}: \mathrm{m} / \mathrm{z} 642.85[\mathrm{M}+\mathrm{H}]^{+} ; 562.90[\mathrm{M}-\mathrm{Br}]^{+}$; $483.02[\mathrm{M}-2 \mathrm{Br}+\mathrm{H}]^{+}$. Anal. Found (calcd for $\mathrm{C}_{12} \mathrm{H}_{16} \mathrm{Br}_{3} \mathrm{FN} 2 \mathrm{Pt}$ ): C, 22.38 (22.45); H, 2.65 (2.51); N, 3.99 (4.36). 
$\left[\mathrm{PtI}_{3}\left\{\left(\mathrm{CH}_{3}\right)_{2} \mathbf{N}\left(\mathrm{CH}_{2}\right)_{3} \mathbf{N}=\mathbf{C H}\left(4-\mathbf{F C}_{6} \mathrm{H}_{3}\right)\right\}\right](\mathbf{4 c})$ was prepared as a dark brown solid by following the same method from $0.035 \mathrm{~g}(0.058 \mathrm{mmols})$ of $\left[\mathrm{PtI}\left\{\left(\mathrm{CH}_{3}\right)_{2} \mathrm{~N}\left(\mathrm{CH}_{2}\right)_{3} \mathrm{~N}=\mathrm{CH}(4-\right.\right.$ $\left.\left.\left.\mathrm{FC}_{6} \mathrm{H}_{3}\right)\right\}\right]$ (2c) and $0.059 \mathrm{~g}(0.232 \mathrm{mmols})$ of $\mathrm{I}_{2}$. Yield: $0.043 \mathrm{~g}(93 \%) .{ }^{1} \mathbf{H} \mathbf{N M R}\left(\mathrm{CDCl}_{3}\right.$, $400 \mathrm{MHz}): \delta 8.25\left[\mathrm{dd}, 1 \mathrm{H},{ }^{3} \mathrm{~J}(\mathrm{Pt}-\mathrm{H})=33.6,{ }^{3} \mathrm{~J}(\mathrm{~F}-\mathrm{H})=10.3,{ }^{4} \mathrm{~J}(\mathrm{H}-\mathrm{H})=2.4, \mathrm{H}^{\mathrm{a}}\right] ; 7.96[\mathrm{~s}$, $\left.1 \mathrm{H},{ }^{3} \mathrm{~J}(\mathrm{Pt}-\mathrm{H})=91.2, \mathrm{H}^{\mathrm{d}}\right] ; 7.52\left[\mathrm{dd}, 1 \mathrm{H},{ }^{3} \mathrm{~J}(\mathrm{H}-\mathrm{H})=8.2,{ }^{4} \mathrm{~J}(\mathrm{~F}-\mathrm{H})=5.9, \mathrm{H}^{\mathrm{c}}\right] ; 6.66[\mathrm{td}, 1 \mathrm{H}$, $\left.{ }^{3} \mathrm{~J}(\mathrm{~F}-\mathrm{H})={ }^{3} \mathrm{~J}(\mathrm{H}-\mathrm{H})=8.3,{ }^{4} \mathrm{~J}(\mathrm{H}-\mathrm{H})=2.4, \mathrm{H}^{\mathrm{b}}\right] ; 3.96\left[\mathrm{t}, 2 \mathrm{H},{ }^{3} \mathrm{~J}(\mathrm{H}-\mathrm{H})=5.6, \mathrm{H}^{\mathrm{e}}\right] ; 3.55[\mathrm{~s}, 6 \mathrm{H}$, $\left.{ }^{3} \mathbf{J}(\mathrm{Pt}-\mathrm{H})=16.6, \mathrm{H}^{\mathrm{h}}\right] ; 2.92\left[\mathrm{~m}, 2 \mathrm{H}, \mathrm{H}^{\mathrm{g}}\right] ; 2.32\left[\mathrm{qi}, 2 \mathrm{H},{ }^{3} \mathrm{~J}(\mathrm{H}-\mathrm{H})=5.2, \mathrm{H}^{\mathrm{f}}\right] .{ }^{19} \mathbf{F} \mathbf{N M R}\left(\mathrm{CDCl}_{3}\right.$, $376.5 \mathrm{MHz}): \delta-97.45[\mathrm{~m}, 1 \mathrm{~F}]$. MS-ESI $^{+}: \mathrm{m} / \mathrm{z} 783.82[\mathrm{M}+\mathrm{H}]^{+}, 655.90[\mathrm{M}-\mathrm{I}]^{+}, 529.00[\mathrm{M}-$ 2I-H] $]^{+}$. Anal. Found (calcd for $\left.\mathrm{C}_{12} \mathrm{H}_{16} \mathrm{I}_{3} \mathrm{FN}_{2} \mathrm{Pt} \cdot 1 / 2 \mathrm{I}_{2}\right)$ : C, 15.44 (15.84); H, 1.87 (1.77); N, $2.82(3.08)$.

\section{$\mathrm{X}$ ray diffraction}

Suitable crystals of compounds $\mathbf{I b}, \mathbf{2 b}, \mathbf{3 b}$ and $\mathbf{4 b}$ were grown at room temperature in dichloromethane-methanol. X-ray diffraction data were collected for prism-like specimens on a D8 VENTURE system equipped with a multilayer monochromator and a Mo high brilliance Incoatec Microfocus Source $(\lambda=0.71073 \AA)$ at $100 \mathrm{~K}(\mathbf{1 b}, \mathbf{3 b}$ and $\mathbf{4 b})$ or at $293 \mathrm{~K}(\mathbf{2 b})$. The structures were solved and refined using the Bruker SHELXTL Software package. ${ }^{38}$ Crystallographic details are given in Table 4. 
Table 4. Crystal data and structure refinement for $\mathbf{I b}, \mathbf{2 b}, \mathbf{3 b}$ and $\mathbf{4 b}$.

\begin{tabular}{|c|c|c|c|c|}
\hline Compound & Ib & $2 \mathbf{b}$ & $\mathbf{3 b}$ & $4 b$ \\
\hline Formula & $\mathrm{C}_{12} \mathrm{H}_{17} \mathrm{Br}_{2} \mathrm{FN}_{2} \mathrm{Pt}$ & $\mathrm{C}_{12} \mathrm{H}_{16} \mathrm{BrFN}_{2} \mathrm{Pt}$ & $\mathrm{C}_{13} \mathrm{H}_{19} \mathrm{Br}_{2} \mathrm{FN}_{2} \mathrm{Pt}$ & $\mathrm{C}_{12} \mathrm{H}_{16} \mathrm{Br}_{3} \mathrm{FN}_{2} \mathrm{Pt}$ \\
\hline Crystal size, $\mathrm{mm}$ & $0.065 \times 0.154 \times 0.213$ & $0.305 \times 0.103 \times 0.054$ & $0.252 \times 0.127 \times 0.076$ & $0.306 \times 0.174 \times 0.072$ \\
\hline $\mathrm{Fw}$ & 563.18 & 482.27 & 577.21 & 642.09 \\
\hline Temp, K & $100(2)$ & $293(2)$ & $100(2)$ & $100(2)$ \\
\hline Wavelength, Å & 0.71073 & 0.71073 & 0.71073 & 0.71073 \\
\hline Crystal system & triclinic & monoclinic & monoclinic & orthorhombic \\
\hline Space group & P-1 & $\mathrm{P} 2{ }_{1} / \mathrm{c}$ & $\mathrm{P} 2{ }_{1} / \mathrm{c}$ & Pna2 $_{1}$ \\
\hline $\mathrm{a}, \AA$ & $10.7938(5)$ & $15.4189(18)$ & $8.0750(3)$ & $15.9976(6)$ \\
\hline $\mathrm{b}, \AA$ & $11.4007(5)$ & $8.7061(10)$ & $8.1606(3)$ & $7.1424(3)$ \\
\hline $\mathrm{c}, \AA$ & $13.4215(7)$ & $30.311(3)$ & 23.9013(9) & $13.7123(5)$ \\
\hline$\alpha,{ }^{o}$ & $89.584(2)$ & 90 & 90.0 & 90.0 \\
\hline$\beta,{ }^{\circ}$ & $75.569(2)$ & $104.344(4)$ & $98.3600(10)$ & 90 \\
\hline$\gamma,{ }^{o}$ & $71.945(2)$ & 90 & 90.0 & 90.0 \\
\hline Volume, $\AA^{3}$ & $1516.34(13)$ & $3942.1(8)$ & $1720.06(12)$ & $1566.78(11)$ \\
\hline $\mathrm{Z}$ & 4 & 12 & 4 & 4 \\
\hline $\mathrm{D}_{\text {calc }}, \mathrm{mg} / \mathrm{m}^{3}$ & 2.467 & 2.438 & 2.460 & 2.722 \\
\hline abs. coef., $\mathrm{mm}^{-1}$ & 14.519 & 13.710 & 14.131 & 16.604 \\
\hline
\end{tabular}




\begin{tabular}{|c|c|c|c|c|}
\hline $\mathrm{F}(000)$ & 1040 & 2688 & 1072 & 1176 \\
\hline$\theta$ range for data coll, ${ }^{\circ}$ & 2.560 to 30.562 & 2.440 to 30.628 & 2.549 to 30.539 & 2.546 to 30.533 \\
\hline Reflns coll. / independent & 88505 / 9284 & $95319 / 12130$ & $50.737 / 4732$ & $20770 / 4695$ \\
\hline Data/restraint /parameters & $9284 / 0 / 329$ & $12130 / 0 / 466$ & $4732 / 2 / 175$ & $4695 / 3 / 174$ \\
\hline GOF on $\mathrm{F}^{2}$ & 1.029 & 1.012 & 1.106 & 1.046 \\
\hline Final R index $(\mathrm{I}>2 \sigma(\mathrm{I}))$ & $\begin{array}{l}\mathrm{R} 1=0.0212, \\
\mathrm{wR} 2=0.0541\end{array}$ & $\begin{array}{l}\mathrm{R} 1=0.0604, \\
\mathrm{wR} 2=0.0718\end{array}$ & $\begin{array}{l}\mathrm{R} 1=0.0197, \\
\mathrm{wR} 2=0.0444\end{array}$ & $\begin{array}{l}\mathrm{R} 1=0.0300, \\
\mathrm{wR} 2=0.0673\end{array}$ \\
\hline $\mathrm{R}$ index (all data) & $\begin{array}{l}\mathrm{R} 1=0.0242, \\
\mathrm{wR} 2=0.0554\end{array}$ & $\begin{array}{l}\mathrm{R} 1=0.1368, \\
\mathrm{wR} 2=0.0858\end{array}$ & $\begin{array}{l}\mathrm{R} 1=0.0235, \\
\mathrm{wR} 2=0.0458\end{array}$ & $\begin{array}{l}\mathrm{R} 1=0.0376, \\
\mathrm{wR} 2=0.0707\end{array}$ \\
\hline Peak and hole, e $\AA^{-3}$ & 1.832 and -2.092 & 3.091 and -3.050 & 1.402 and -1.515 & 1.049 and -2.385 \\
\hline CCDC numbers & 1856035 & 1856038 & 1856037 & 1856036 \\
\hline
\end{tabular}




\section{Supporting Information Available}

Fig. S1 and S4 showing the aromatic region of the ${ }^{1} \mathrm{H}$ NMR spectra, fig. S2-S3 showing the unit cell of compounds Ib and $\mathbf{2 b}$, fig. S5 and S6 showing the packing of compounds $\mathbf{3 b}$ and $\mathbf{4 b}$, fig. S7-S9 showing the absorption spectra of the platinum compounds and the ligand, fig S10-S15 showing the emission spectra of the platinum compounds and the ligand. The crystallographic data of compounds $\mathbf{I b}, \mathbf{2} \mathbf{b}, \mathbf{3 b}$ and $\mathbf{4 b}$ have been deposited with the Cambridge Crystallographic Data Centre, CCDC No. 1856035-1856038.

\section{Conflicts of interest}

There are no conflicts of interest to declare.

\section{Acknowledgements}

This work was supported by the Ministerio de Economia y Competitividad (Grants CTQ2015-65040-P, CTQ-2015-65707-C2-1-P and AEI/FEDER, UE Project CTQ201676120-P). 


\section{REFERENCES}

[1] J.A.G. Williams, S. Develay, D.L. Rochester, L. Murphy, Optimising the luminescence of platinum(II) complexes and their application in organic light emitting devices (OLEDs), Coord. Chem. Rev. 252 (2008) 2596-2611. doi:10.1016/j.ccr.2008.03.014.

[2] J. Kalinowski, V. Fattori, M. Cocchi, J.A.G. Williams, Light-emitting devices based on organometallic platinum complexes as emitters, Coord. Chem. Rev. 255 (2011) 2401-2425. doi:10.1016/j.ccr.2011.01.049.

[3] S. Huo, J. Carroll, D.A.K. Vezzu, Design, Synthesis, and Applications of Highly Phosphorescent Cyclometalated Platinum Complexes, Asian J. Org. Chem. 4 (2015) 1210-1245. doi:10.1002/ajoc.201500246.

[4] T. Fleetham, G. Li, J. Li, Phosphorescent Pt(II) and Pd(II) Complexes for Efficient, High-ColorQuality, and Stable OLEDs, Adv. Mater. 29 (2017) 1-16. doi:10.1002/adma.201601861.

[5] J.R. Berenguer, J.G. Pichel, N. Giménez, E. Lalinde, M.T. Moreno, S. Piñeiro-Hermida, Luminescent pentafluorophenyl-cycloplatinated complexes: synthesis, characterization, photophysics, cytotoxicity and cellular imaging, Dalton Trans. 44 (2015) 18839-18855. doi:10.1039/C5DT02721G.

[6] Y. Zhang, Q. Luo, W. Zheng, Z. Wang, Y. Lin, E. Zhang, S. Lü, J. Xiang, Y. Zhao, F. Wang, Luminescent cyclometallated platinum(II) complexes: highly promising EGFR/DNA probes and dual-targeting anticancer agents, Inorg. Chem. Front. 5 (2018) 413-424. doi:10.1039/C7QI00346C.

[7] V. Fernández-Moreira, M.C. Gimeno, Heterobimetallic Complexes for Theranostic Applications, Chem. - A Eur. J. 24 (2018) 3345-3353. doi:10.1002/chem.201705335.

[8] F. Juliá, D. Bautista, P. González-Herrero, Developing strongly luminescent platinum(IV) complexes: facile synthesis of bis-cyclometalated neutral emitters, Chem. Commun. 2 (2016) 1657-1660. doi:10.1039/C5CC09566B.

[9] F. Juliá, M.D. García-Legaz, D. Bautista, P. González-Herrero, Influence of Ancillary Ligands and Isomerism on the Luminescence of Bis-cyclometalated Platinum(IV) Complexes, Inorg. Chem. 55 (2016) 7647-7660. doi:10.1021/acs.inorgchem.6b01100.

[10] J.R. Berenguer, E. Lalinde, M.T. Moreno, Luminescent cyclometalated-pentafluorophenyl PtII, PtIVand heteropolynuclear complexes, Coord. Chem. Rev. 366 (2018) 69-90. doi:10.1016/j.ccr.2018.04.002.

[11] A. Gandioso, J. Valle-Sistac, L. Rodríguez, M. Crespo, M. Font-Bardía, Platinum(II) compounds containing cyclometalated tridentate ligands: Synthesis, luminescence studies, and a selective fluoro for methoxy substitution, Organometallics. 33 (2014) 561-570. doi:10.1021/om401111t.

[12] A. Capapé, M. Crespo, J. Granell, M. Font-Bardía, X. Solans, Synthesis and reactivity of cyclometallated platinum (II) compounds containing [C,N,N'] terdentate ligands: Crystal structures of $[\mathrm{PtCl}\{(\mathrm{CH} 3) 2 \mathrm{~N}(\mathrm{CH} 2) 3 \mathrm{NCH}(4-\mathrm{ClC} 6 \mathrm{H} 3)\}], \quad[\mathrm{PtCl}\{(\mathrm{CH} 3) 2 \mathrm{~N}(\mathrm{CH} 2) 3 \mathrm{NCH}(2-\mathrm{ClC} 6 \mathrm{H} 3)\}], \quad J$. Organomet. Chem. 690 (2005) 4309-4318. doi:10.1016/j.jorganchem.2005.06.038.

[13] M. Crespo, M. Font-Bardia, J. Granell, M. Martínez, X. Solans, Cyclometallation on platinum(II) complexes; the role of the solvent and added base donor capability on the reaction mechanisms, Dalton Trans. (2003) 3763-3769. doi:10.1039/.

[14] E. Bauer, X. Domingo, C. Balcells, I.H. Polat, M. Crespo, J. Quirante, J. Badía, L. Baldomà, M. Font-Bardia, M. Cascante, Synthesis, characterization and biological activity of new cyclometallated platinum(IV) iodido complexes, Dalton Trans. 46 (2017) 14973-14987. doi:10.1039/c7dt03448b.

[15] P.V. Bernhardt, T. Calvet, M, Crespo, M. Font-Bardia, S. Jansat, M. Martinez, New insights in the formation of five- versus seven-membered platinacycles: a kinetico-mechanistic study, Inorg. Chem. 52 (2013) 474-484.

[16] M. Crespo, M. Font-Bardía, X. Solans, A comparative study of metallating agents in the synthesis of [C,N,N']-cycloplatinated compounds derived from biphenylimines, J. Organomet. Chem. 691 (2006) 1897-1906. doi:10.1016/j.jorganchem.2006.01.011.

[17 M. Kaupp, O.L. Malkina, V.G. Malkin, P. Pyykkö, How do spin-orbit-induced heavy-atom effects on NMR chemical shifts function? Validation of a simple analogy to spin-spin coupling by density functional theory (DFT) calculations on some iodo compounds. Chem.Eur. J. 4 (1998) 118-126.

[18] J.J. Wilson, S.J. Lippard, Synthetic methods for the preparation of platinum anticancer complexes, Chem. Rev. 114 (2014) 4470-4495. doi:10.1021/cr4004314.

[19] T.C. Johnstone, S.M. Alexander, J.J. Wilson, S.J. Lippard, Oxidative halogenation of cisplatin and carboplatin: synthesis, spectroscopy, and crystal and molecular structures of $\mathrm{Pt}(\mathrm{IV})$ prodrugs., Dalton Trans. 44 (2015) 119-29. doi:10.1039/c4dt02627f.

[20] L. Rendina, R. Puddephatt, Oxidative Addition Reactions of Organoplatinum (II) Complexes with 
Nitrogen-Donor Ligands, Chem. Rev. 97 (1997) 1735-1754. doi:10.1021/cr9704671.

[21] S.M. Nabavizadeh, H. Amini, M. Rashidi, K.R. Pellarin, M.S. McCready, B.F.T. Cooper, R.J. Puddephatt, The mechanism of oxidative addition of iodine to a dimethylplatinum(II) complex, J. Organomet. Chem. 713 (2012) 60-67. doi:10.1016/j.jorganchem.2012.04.017.

[22] C.M. Anderson, M. Crespo, M.C. Jennings, A.J. Lough, G. Ferguson, R.J. Puddephatt, Competition between intramolecular oxidative addition and ortho metalation in organoplatinum(II) compounds: activation of aryl-halogen bonds, Organometallics. $10 \quad$ (1991) 2672-2679. doi:10.1021/om00054a031.

[23] T. Calvet, M. Crespo, M. Font-Bardía, S. Jansat, M. Martínez, Kinetico-mechanistic studies on intramolecular $\mathrm{C}-\mathrm{X}$ bond activation $(\mathrm{X}=\mathrm{Br}, \mathrm{Cl})$ of amino-imino ligands on $\mathrm{Pt}(\mathrm{II})$ compounds. prevalence of a concerted mechanism in nonpolar, polar, and ionic liquid media, Organometallics. 31 (2012) 4367-4373. doi:10.1021/om300374f.

[24] M. Solé, C. Balcells, M. Crespo, J. Quirante, J. Badia, L. Baldomà, M. Font-Bardia, M. Cascante, Synthesis, characterization and biological activity of new cyclometallated platinum(IV) complexes containing a para-tolyl ligand, Dalton Trans. 47 (2018) 8956-8971. doi:10.1039/c3dt52077c.

[25] D. Kourkoulos, C. Karakus, D. Hertel, R. Alle, K. Meerholz, Dalton Trans., 42 (2013) 1361213621. doi:10.1039/c3dt50364j.

[26] L.M. Hight, M.C. Mcguire, Y. Zhang, M.A. Bork, P.E. Fanwick, A. Wasserman, D.R. Mcmillin, $\pi$ Donation and Its Effects on the Excited-State Lifetimes of Luminescent Platinum(II) Terpyridine Complexes in Solution, Inorg. Chem. 52 (2013) 8476-8482. doi:10.1021/ic4004643.

[27] E. Viola, M.P. Donzello, C. Ercolani, C. Rizzoli, A.B.P. Lever, Synthesis and structure of rare zwitterionic complexes involving the presence of $\mathrm{N}_{(\mathrm{py})} \mathrm{MCl}_{3}{ }^{-}$moieties $(\mathrm{M}=\mathrm{Pt}(\mathrm{II}), \mathrm{Pd}(\mathrm{II}))$, Inorg. Chim. Acta. 480 (2018) 101-107. doi:10.1016/j.ica.2018.04.031.

[28] C. Song, J. Tang, J. Li, Z. Wang, P. Li, H. Zhang, Quantum-Chemical Insights into the Phosphorescence Efficiencies of Blue-Emitting Platinum Complexes with Phenylene-Bridged Pincer Ligands, Inorg. Chem. (2018). doi:10.1021/acs.inorgchem.8b01828.

[29] K. Li, Q. Wan, C. Yang, X.-Y..Chang, K.-H. Low, C.-M. Che, Angew. Chem. Int .Ed. (2018). doi:10.1002/ange.201808642.

[30] Y. Zhang, F. Meng, C. You, S. Yang, L. Xiong, W. Xion, W. Zhu, Y. Yang, Y. Pei, S. Su, Dyes and Pigments Efficient near-infrared emitting tetradentate bis-cyclometalated platinum (I ) complexes for solution-processed polymer light- emitting diodes, Dye Pigment. 142 (2017) 457464. doi:10.1016/j.dyepig.2017.04.002.

[31] F. Juliá, P. González-Herrero, Spotlight on the ligand: luminescent cyclometalated Pt(IV) complexes containing a fluorenyl moiety, Dalton Trans. 45 (2016) 10599-10608. doi:10.1039/c6dt01722c.

[32] E.V. Puttock, M.T. Walden, J.A.G. Williams, The luminescence properties of multinuclear platinum complexes, Coord. Chem. Rev. 367 (2018) 127-162. doi:10.1016/j.ccr.2018.04.003.

[33] J. Li, P.I. Djurovich, B.D. Alleyne, M. Yousufuddin, N.N. Ho, J.C. Thomas, J.C. Peters, R. Bau, M.E. Thompson, Synthetic Control of Excited-State Properties in Cyclometalated Ir(III) Complexes Using Ancillary Ligands, 44 (2005) 1713-1727. doi:10.1021/ic048599h.

[34] J.E.. Expósito, M.. Alvarez-Paíno, G.. Aullón, J.A. Miguel, P. Espinet, Higher fluorescence in platinum(IV) orthometallated complexes of perylene imine compared with their platinum (II) or palladium (II) analogues, Dalton Trans. 44 (2015) 16164-16176. doi:10.1039/c5dt02572a.

[35] J.M.G. Martinho, Heavy atom quenching of monomer and excimer pyrenes. J. Phys. Chem. 93 (1989) 6687-6692.

[36] T.A.K. Al-Allaf, L.J. Rashan, A.S. Abu-Surrah, R. Fawzi, M. Steimann, Chemical properties and cytotoxic activity of complexes of platinum(II) and palladium(II) containing dmso and various anions; synthesis and structural characterization of $[\mathrm{Pt}(\mathrm{dmso}) 2\{\mathrm{O} 2(\mathrm{CO}) 2 \mathrm{CCH} 2 \mathrm{CH} 2 \mathrm{CH} 2\}]$, Trans. Met. Chem. 23 (1998) 403-406. doi:10.1023/A:1006942125847.

[37] M. Crespo, M. Font-Bardia, P. Hamidizadeh, M. Martínez, S.M. Nabavizadeh, Kineticomechanistic study on the reduction/complexation sequence of PtIV/PtII oganometallic complexes by thiol-containing biological molecules. Inorg. Chim. Acta.486 (2019) 8-16. doi.org/10.1016/j.ica.2018.10.021

[38] G.M. Sheldrick, Crystal structure refinement with SHELXL Acta Crystallogr. Sect. C. 71 (2015) 3-8. 